\title{
低炭素都市の実現に向けた都市計画と省エネル ギー計画の統合マネジメントモデルの開発
}

\author{
前田 秀人 1 -中久保 豊彦 2 -東海 明宏 3 \\ 1非会員 西日本旅客鉄道株式会社（†530-8341 大阪市北区芝田二丁目4-24） \\ 2学生会員 大阪大学大学院博士後期課程 工学研究科（二565-0871 吹田市山田丘2-1） \\ E-mail:nakakubo@em.see.eng.osaka-u.ac.jp \\ 3正会員 大阪大学大学院教授 工学研究科（同上）
}

\begin{abstract}
本研究では都市計画と連動して街区レベルでの省エネルギー計画を策定するための統合マネジメントモ デルを開発し，大阪市に適用した。都市構造ケースとして，建物の集積度合いが異なる3ケースを設定し た，省エネルギー計画として，個別電化ヒートポンプを導入する施策，マイクログリッドを導入する施策 と, 各街区で $\mathrm{CO}_{2}$ 削減効果が高い方を選択導入する施策を設定し, 各都市構造ケース下での施策導入効果 を $\mathrm{CO}_{2}$ 排出量で評価した。 結果，2050年における各ケースの $\mathrm{CO}_{2}$ 排出削減率（現状比）は $54.8 \sim 57.6 \%$ と推 計され，都市構造ケース間で差が見られなかった。 ケース閒比較では，傾向延長下で選択導入するケース の削減効果が最も大きく, 都市高密化による熱の融通利用効果よりも太陽光発電の導入効果が上回ること が示唆された.
\end{abstract}

Key Words : low-carbon city, urban planning, energy planning, smart energy system, $\mathrm{CO}_{2}$ reduction

\section{1. はじめに}

地球温暖化や我が国のエネルギーセキュリティを背景 として， $\mathrm{CO}_{2}$ 排出量を長期的には大幅に削減させる努力 が求められている．中でも近年増加傾向が顕著な都市民 生部門において大幅な $\mathrm{CO}_{2}$ 排出削減を達成するためには, 機器の効率向上や建物の断熱性向上など機器・建物レ心゙ ルの対策に留まらず，地域・街区レベルでエネルギーを 効率的に利用できるシステムを構築することが必要であ ることが示されている1, 2)，一方，将来の人口減少局面 に向け，コンパクトシティへの転換が検討されるなど゙, 我が国の多くの都市において都市構造の再構築を検討寸 る段階にある，そこで，長期的な視野に立ち，街区レべ ルで太陽光発電や燃料電池を効率的に運用寸る要件を満 たすように建物床面積の誘導を行う都市計画と連動して, 省エネルギー計画を具体化させることが必要視される.

近年では, 都市計画の分野でも民生部門の温暖化対策 として都市構造や土地利用の変更と連動した対策の必要 性が問われ始めている4゙.しかし, 実際の都市計画マス タープランは, 特例制度や先進的事例が展開されている 一部の地区での開発に力点が置かれており, 都市全体を どのように再構築するかは検討されていない，一方，エ
ネルギー管理の観点から望ましい都市の形態を議論する 研究も複数存在するが5 の, 省エネルギ一性を第1として 都市構造を積極的に転換するという提案が多く, 現実の 都市計画との整合を図る必要性があるとともに, 将来の 床面積需要の変化を踏まえた上で, 建物更新の時間断面 が考慮されていないことが，研究課題として挙げられる. そこで本研究では, 現状ストックからの経年的な建物 更新，都市構造転換のための制度設計が検討可能な集約 型都市設計モデルと, 将来の都市全体の建物において個 別/街区単位の施策が導入された場合の民生用エネルギ 一消費量・ $\mathrm{CO}_{2}$ 排出量を算定できる省エネルギーシステ ム導入評価モデルから構成される, 統合マネジメントモ デルを開発した（図-1）。先行研究である横井ら》は, 産業構造・人口の異なる将来シナリ才間の評価を行って おり，建物集積の効果に特化した分析を行っていない. そこで本研究では，集約型都市設計モデルにより都市全 体の用途別建物床面積を $250 \times 250 \mathrm{~m}$ メッシュで表現し， 集積方策の差異を分析することを目的とした．また，都 市計画制度（容積率や用途地域の指定）の違いを考慮可 能とし，自治体による政策策定に貢献できるモデル構造 とした．モデルの適用地域は大阪市とし，2005〜2050年 を対象としてケーススタディを行った. 


\section{2. 集約型都市設計モデルの構築}

\section{(1) モデルの概要}

本モデルは，現状のストックから将来の更新床面積を 推計する(1)更新床面積算定モデル，新規建設床面積推 計のための(2)将来床面積需要推計モデル，将来及び現 状の用途地域を設定する(3)用途地域設定モデル，更新 床面積から受入可能床面積と新規建設床面積を算出する (4)建設床面積算出モデル，そして各メッシュにおいて 建設される着工床面積を計算する(5)床面積配分モデル から構成される．これにより，建物の建て替わりの時期 に合わせて床面積を順次移動させていくことで都市構造 の転換を表現できる．現状（2005年）から2050年まで5 年ごとの床面積ストックを算出することとした. 各サブ モデルにおける推計は，250×250mメッシュで行った。

\section{（2）都市構造のケース設定}

本研究では，都市の集約度合いにより3つのケース （多極高度集約，多極普通集約，傾向延長）を設定する. 多極高度集約ケースは，商住混在比率を高めるための 新たな用途地域が設定され，容積率も大幅に緩和された 都市計画制度の下，建物を複数の拠点（主に駅周辺） 集約させるケースとした．多極普通集約ケースも同様に 建物床面積を集積させるが，都市計画制度の変更に伴う 低炭素効果を考察するため，図-2に示すように現状の用 途地域と容積率の範囲で集約化を実施することを想定す る. 多極高度集約・多極普通集約ケースにおいては，建 物の集約化と合わせて，業務・商業系用途の建物と住居 系建物を適切に混在させる商住混在比率を設定する. 傾 向延長ケースは，現状の拡散傾向にある都市構造が継続 する場合で，集約化を実行しないケースとした.
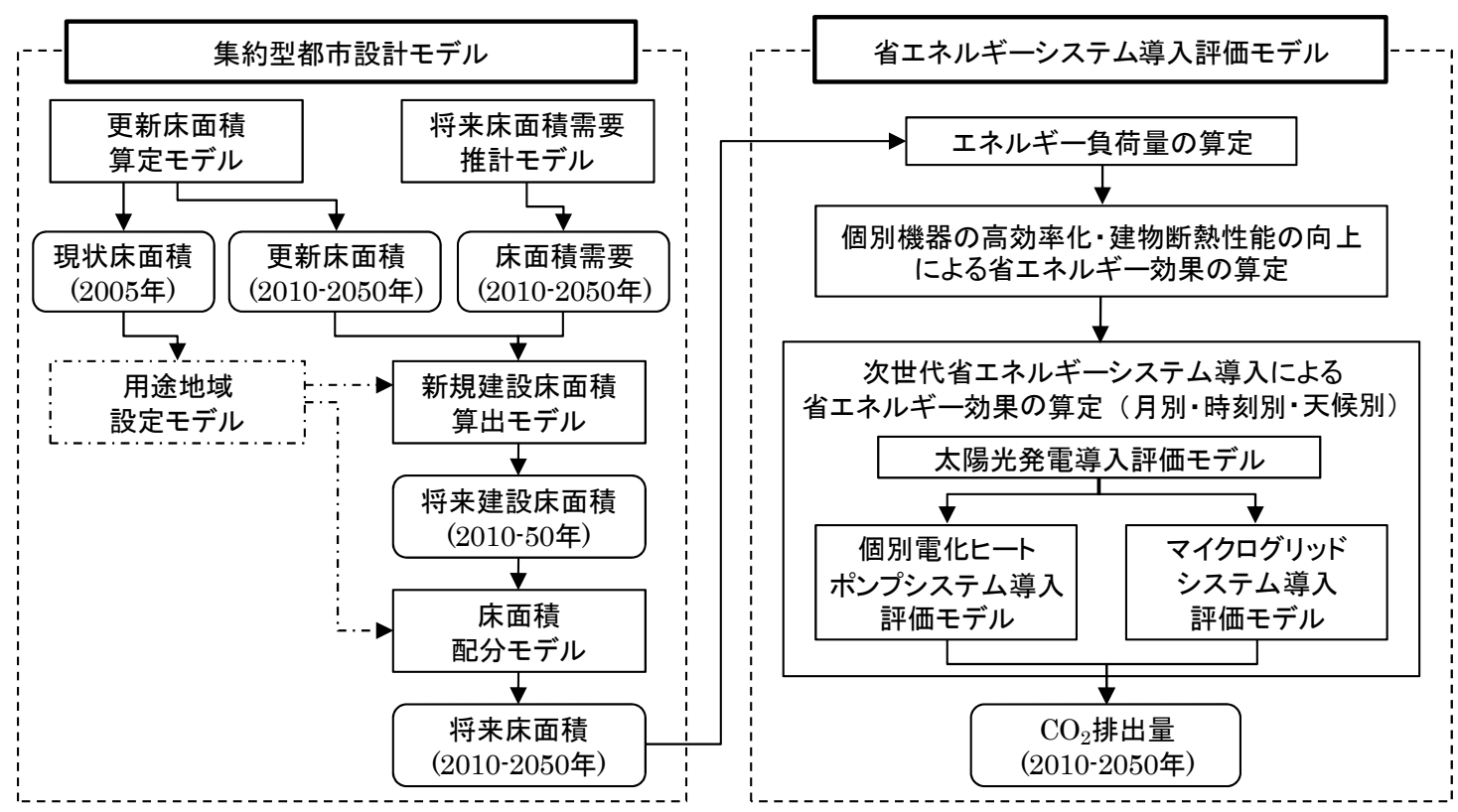

図-1＼cjkstart統合マネジメントモデルの概要

\begin{tabular}{|c|c|c|c|c|c|c|}
\hline \multicolumn{2}{|c|}{$\begin{array}{c}\text { 集約型都市 } \\
\text { ケース }\end{array}$} & \multicolumn{2}{|c|}{ 多極高度集約 } & 多極普通集約 & \multicolumn{2}{|c|}{ 傾向延長 } \\
\hline & & & & $\downarrow$ & & \\
\hline \multirow{3}{*}{ 大別 } & \multicolumn{3}{|c|}{ 新規用途地域 (7つの用途類型) } & \multicolumn{3}{|c|}{ 現在の都市計画区域(12の用途) } \\
\hline & & & & 用途地 & & 容積率 \\
\hline & & 佘地域 & 新容積率 & 近隣商業地域 & & 400 \\
\hline \multirow{3}{*}{$\begin{array}{l}\text { 集積 } \\
\text { 拠点 }\end{array}$} & 高度集 & 㞦点 & 1000 & 商業地域 & & 600 \\
\hline & & & & 第1種中高層住居 & 也域 & \\
\hline & 準集積 & & 800 & 第2種中高層住居 & & 300 \\
\hline \multirow{5}{*}{$\begin{array}{l}\text { 拠 } \\
\text { 点 } \\
\text { 以 } \\
\text { 外 } \\
\text { 地 } \\
\text { 域 }\end{array}$} & 商住混 & 也域 & 400 & 第1種低層住居専 & & 120 \\
\hline & 集合住 & 也域 & 300 & 第1種住居地域 & & \multirow{3}{*}{300} \\
\hline & 戸建専 & 也域 & 120 & $\begin{array}{l}\text { 第2種住居地域 } \\
\text { 準住居地域 }\end{array}$ & & \\
\hline & 多用途 & 主地域 & 300 & 準工業地域 & & \\
\hline & 市街化 & 䇥地域 & 200 & \begin{tabular}{|l} 
工業地域 \\
工業専用地域
\end{tabular} & & 200 \\
\hline
\end{tabular}

図-2 新規都市計画用途地域と新容積率の設定 


\section{（3）更新床面積算定モデル}

\section{a) 現状床面積ストックの計算}

平成18年度建物床面積調査 ${ }^{8}$ による建設年代別・用途 別床面積（1階床面積・延床面積）を，建設年代は5年ご と（1955年以前は10年ごと），建物用途は表-1に示す区 分で整理した. ただし，文教と行政に関しては建物床面 積調查からは得られないため, 平成17年度土地利用現況 調査9よりデータを取得した.

\section{b) 更新床面積の推計}

将来，更新される建物の面積である更新床面積を推計 するために，現状の建物の建物寿命を算定する. まず， 及川 ${ }^{10)}$ の方法を参考に建築の残存率関数 $R(t)$ を式(1)の ように設定した.

$$
\begin{aligned}
& R(t)=\exp \left\{-\left(\frac{t}{\alpha}\right)^{m}\right\} \\
& t: \text { 経年数 } \\
& \alpha, m: \text { パラメータ }
\end{aligned}
$$

パラメータは，及川・占部10)が東京都を対象に調査し 整備した建築構造別の值を, 大阪市建物床面積調查デー タより得られる構造別の延床面積11)で重みづけした值 $(\alpha=51.61 ， m=2.931)$ を用いた。 これより，およそ45 年で残存率が 0.5 (新設建物の半数が建て替え) となっ た.

この残存率関数を用い表-2に示すように建設年代別の 更新時期割合を2050年まで5年ごとに算出した．ただし， 今回ケーススタディで対象とする大阪市には，建設から

表-1 建物用途分類

\begin{tabular}{c|l}
\hline 大分類 & \multicolumn{1}{|c}{ 主要な用途 } \\
\hline \hline 戸建 & 一戸建住宅 \\
\hline 集合 & 共同住宅·長屋住宅·併用住宅 \\
\hline 商業 & 店舗·卸売·百貨店·飲食店·小売店 \\
\hline 業務 & 事務所·金融保険 \\
\hline 宿泊 & 木テル·旅館 \\
\hline 病院 & 病院·保健所 \\
\hline 文教 & 学校·研究施設·図書館·博物館 \\
\hline 行政 & 官公庁·郵便局 \\
\hline
\end{tabular}

50年以上経過している戦前の建物が多く存在し，単純に 残存率関数を適用すると2010年に更新される床面積が非 常に多くなることが確認された．よって，このような建 物に関しては残存率関数に必ずしも沿っていないと考え, 本研究では別途ルールを設け，2030年までに徐々に更新 が進む（5年で20\%ずつ）とした，最後に，更新床面積 割合を建設年代別床面積に乗じることで，将来の更新床 面積を計算した.

\section{(4) 将来床面積需要推計モデル}

本研究では，将来の需要に見合った範囲内で新たな建 物が建設されるという設定を行うため, 将来の床面積需 要を図-3に示寸手順に基づいて推計する.この方法は, 2005年大阪市の家族類型別世帯数，年齢階級別人口，及 び産業別生産額を基本データ11)として用い，それぞれ将 来年間変化率等を設定することで2050年までの用途別床 面積需要を推計するという手順である．なお，前提とな る将来の年齢階級別人口 (年少人口・生産年齢人口・老 年人口）の推計は, 国立社会保障・人口問題研究所 ${ }^{12)} に$ よる2035年までの大阪市の推計值を用い，それ以降はそ の傾向が継続するとして推計值を得た（表-3）。以下， 用途別に説明する.

\section{a) 戸建 ·集合床面積}

将来の家族類型別世帯数は，国立社会保障・人口問題 研究所 ${ }^{12} の 2030$ 年までの推計值を利用し，その傾向が 2050年まで続くとした. 次に, 都市構造のケース別に戸 建比率・集合比率を設定し, 家族類型別の戸建世帯数 集合世帯数を算出する. 戸建・集合比率は2050年の目標 值をケースごとに設定し，それまで線形に比率が変化す るとした（表-4）。この戸建・集合別の世帯数に，都市 全体での戸建・集合の延床面積を世帯数で除して算出し た1世帯当たり床面積原単位を乗じることで，2010年〜 2050年までの戸建・集合住宅の床面積需要を算出した.

\section{b) 業務系（商業·業務 - 宿泊 · 行政）床面積}

\begin{tabular}{|c|c|c|c|c|c|c|c|c|c|c|}
\hline \multirow{2}{*}{ 建設年 } & \multicolumn{9}{|c|}{ 各年代に更新される床面積の割合 } & \multirow{2}{*}{$\begin{array}{l}\text { 更新されない } \\
\text { 床面積の割合 }\end{array}$} \\
\hline & 2010 & 2015 & 2020 & 2025 & 2030 & 2035 & 2040 & 2045 & 2050 & \\
\hline 1925年以前 & $20.0 \%$ & $20.0 \%$ & $20.0 \%$ & $20.0 \%$ & $20.0 \%$ & $0.0 \%$ & $0.0 \%$ & $0.0 \%$ & $0.0 \%$ & $0.0 \%$ \\
\hline 1926 1935年 & $20.0 \%$ & $20.0 \%$ & $20.0 \%$ & $20.0 \%$ & $20.0 \%$ & $0.0 \%$ & $0.0 \%$ & $0.0 \%$ & $0.0 \%$ & $0.0 \%$ \\
\hline 1936 1945年 & $20.0 \%$ & $20.0 \%$ & $20.0 \%$ & $20.0 \%$ & $20.0 \%$ & $0.0 \%$ & $0.0 \%$ & $0.0 \%$ & $0.0 \%$ & $0.0 \%$ \\
\hline 1946 1955年 & $33.7 \%$ & $25.1 \%$ & $17.3 \%$ & $11.0 \%$ & $6.4 \%$ & $3.4 \%$ & $1.7 \%$ & $0.7 \%$ & $0.5 \%$ & $0.0 \%$ \\
\hline 1956 1965年 & $25.4 \%$ & $22.0 \%$ & $17.7 \%$ & $13.2 \%$ & $9.1 \%$ & $5.8 \%$ & $3.4 \%$ & $1.8 \%$ & $0.9 \%$ & $0.6 \%$ \\
\hline 1966 1970年 & $17.7 \%$ & $17.7 \%$ & $16.4 \%$ & $14.2 \%$ & $11.4 \%$ & $8.5 \%$ & $5.9 \%$ & $3.7 \%$ & $2.2 \%$ & $2.1 \%$ \\
\hline 1971 1975年 & $14.2 \%$ & $15.2 \%$ & $15.2 \%$ & $14.1 \%$ & $12.2 \%$ & $9.8 \%$ & $7.3 \%$ & $5.0 \%$ & $3.2 \%$ & $3.7 \%$ \\
\hline 1976 1980年 & $11.0 \%$ & $12.7 \%$ & $13.5 \%$ & $13.5 \%$ & $12.5 \%$ & $10.9 \%$ & $8.7 \%$ & $6.5 \%$ & $4.5 \%$ & $6.2 \%$ \\
\hline 1981 1985年 & $8.1 \%$ & $10.1 \%$ & $11.6 \%$ & $12.4 \%$ & $12.4 \%$ & $11.5 \%$ & $10.0 \%$ & $8.0 \%$ & $6.0 \%$ & $9.8 \%$ \\
\hline 1986 1990年 & $5.6 \%$ & $7.6 \%$ & $9.5 \%$ & $11.0 \%$ & $11.8 \%$ & $11.7 \%$ & $10.9 \%$ & $9.4 \%$ & $7.6 \%$ & $14.9 \%$ \\
\hline 1991 1995年 & $3.5 \%$ & $5.4 \%$ & $7.4 \%$ & $9.2 \%$ & $10.6 \%$ & $11.3 \%$ & $11.3 \%$ & $10.5 \%$ & $9.1 \%$ & $21.7 \%$ \\
\hline 1996 2000年 & $1.8 \%$ & $3.4 \%$ & $5.3 \%$ & $7.2 \%$ & $9.0 \%$ & $10.4 \%$ & $11.1 \%$ & $11.1 \%$ & $10.3 \%$ & $30.2^{\circ}$ \\
\hline 2001年以降 & $0.1 \%$ & $0.7 \%$ & $1.8 \%$ & $3.4 \%$ & $5.2 \%$ & $7.2 \%$ & $9.0 \%$ & $10.3 \%$ & $11.0 \%$ & $51.2^{\circ}$ \\
\hline
\end{tabular}

業務系の将来床面積は，産業分類別産業出荷額 ${ }^{133}$ より

表-2 建設年代別将来更新される床面積割合 
推計する．表-5に示寸ように，大阪市の産業出荷額の年 間変化率 ${ }^{14)}$ 設定した．次に，大阪市国勢調査 ${ }^{11)}$ と建物 現況調査 ${ }^{8}$ より得られる就業者数と用途別の業務系延床 面積より，就業者一人あたり床面積原単位を用途別に算 出する．ただし，就業者一人あたりの床面積は年代とと もに増加傾向にある. そこで本研究では, 年代別に就業 者一人あたりの床面積原単位を設定する，過去の国勢調 査より1995年から2005年までの就業者一人あたり床面積 原単位の変化率を求め, その傾向が2050年まで続くとし た. 将来の就業者数変化は, 現状2005年の就業者数に, 生産年齢人口の変化率を乗じて求めた. 以上で求められ た就業者一人あたり床面積原単位に将来の就業者数を乗 じることにより, 将来の業務系床面積需要を推計した.

\section{c) 文教 $\cdot$ 病院床面積}

文教床面積の推計には年少人口，病院床面積には老年 人口の将来推計值 ${ }^{12)}$ 用いる. この将来推計人口に，年 少人口一人あたり文教床面積原単位 $30.73 \mathrm{~m}^{2} / 人$, 及び老 年人口一人あたり病院床面積原単位 $3.21 \mathrm{~m}^{2} /$ 人を乗じ (2005年の国勢調查 ${ }^{11)}$ ・建物床面積調査 ${ }^{8}$ より得られる值 を用いて推算）, 将来の文教・病院床面積を推計した.

\section{（5）用途地域設定モデル}

多極普通集約ケース，傾向延長ケースは現状用途地域 推定サブモデルを，新規都市計画用途地域を用いる多極 高度集約ケースは拠点選定サブモデルを利用する.

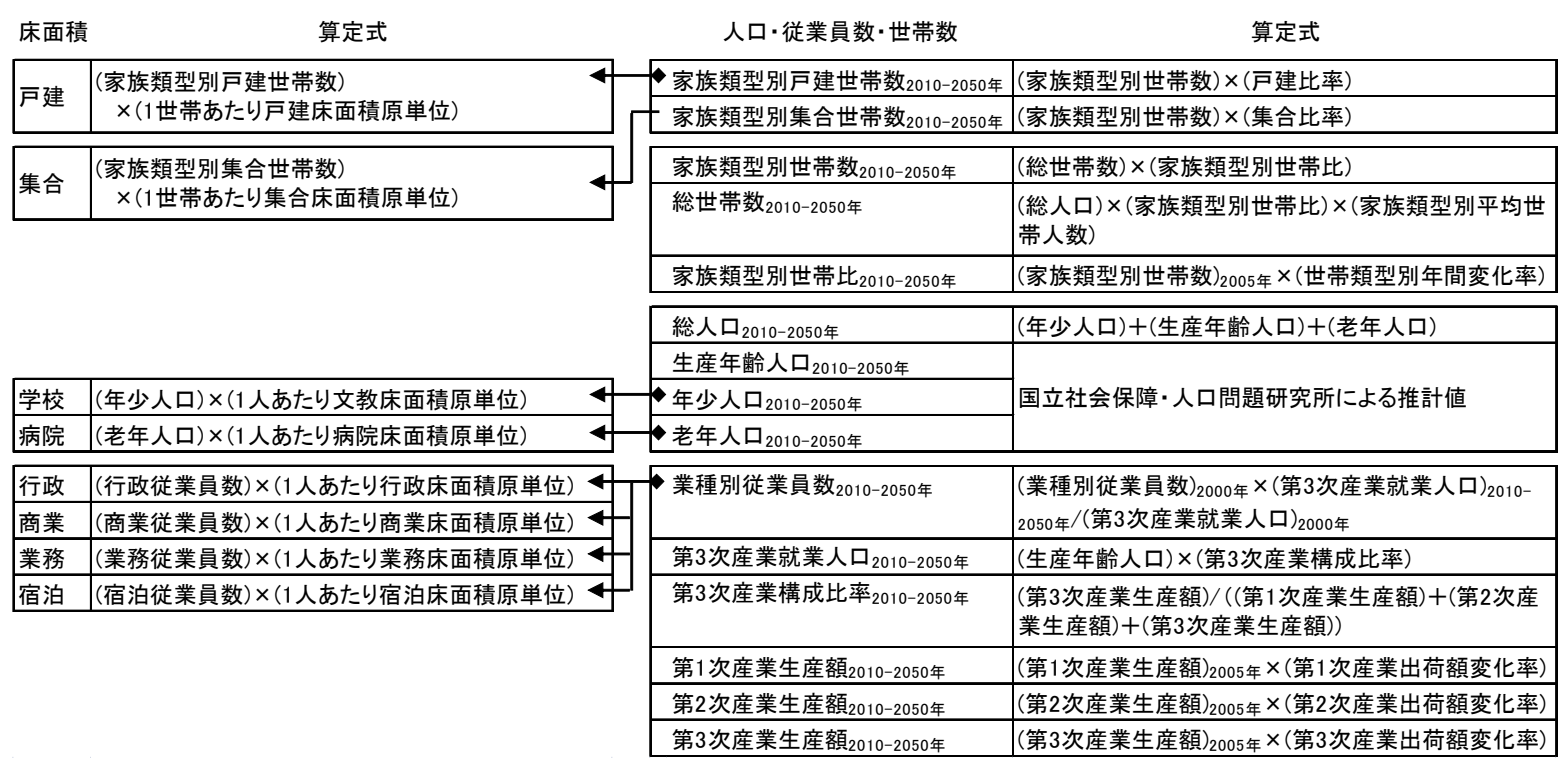

図-3 将来床面積需要の推計手法

表-3 大阪市の将来人口の推計（人）

\begin{tabular}{|c|c|c|c|c|c|c|c|c|c|c|}
\hline & 現状 & 2010年 & 2015 年 & 2020年 & 2025 年 & 2030年 & 2035年 & 2040年 & 2045年 & 2050年 \\
\hline 年少人口 & $\overline{319,901}$ & 303,607 & 272,615 & $\overline{2440,413}$ & 216,759 & $\overline{203,564}$ & $\overline{192,777}$ & $\overline{187,176}$ & $\begin{array}{l}181,773 \\
\end{array}$ & $\overline{177,020}$ \\
\hline 生産年齢人口 & $1,772,951$ & $1,696,163$ & $1,605,587$ & $1,558,446$ & $1,517,884$ & $1,440,288$ & $1,333,693$ & $1,298,374$ & $1,218,917$ & $1,137,770$ \\
\hline 老年人口 & 535,959 & 614,554 & 694,119 & 713,225 & 702,506 & 706,189 & 725,748 & 760,971 & 774,809 & 787,400 \\
\hline 合計 & $2,628,811$ & $2,614,324$ & $2,572,321$ & $2,512,084$ & $2,437,149$ & $2,350,041$ & $2,252,218$ & $2,246,521$ & $2,175,498$ & $2,102,190$ \\
\hline
\end{tabular}

表-4 戸建比率ならびに集合比率の設定（ - )

\begin{tabular}{c|c|rrrrrrrrrr}
\hline \multicolumn{2}{c|}{ 都市構造ケース } & 2005 年 & 2010 年 & 2015 年 & 2020 年 & 2025 年 & 2030 年 & 2035 年 & 2040 年 & 2045 年 & 2050 年 \\
\hline 多極高度集約 & 戸建 & 0.24 & 0.23 & 0.23 & 0.22 & 0.22 & 0.22 & 0.21 & 0.21 & 0.20 & 0.20 \\
\cline { 2 - 14 } 多極普通集約 & 集合 & 0.76 & 0.77 & 0.77 & 0.78 & 0.78 & 0.78 & 0.79 & 0.79 & 0.80 & 0.80 \\
\hline \multirow{2}{*}{ 傾向延長 } & 戸建 & 0.24 & 0.24 & 0.24 & 0.24 & 0.24 & 0.24 & 0.24 & 0.24 & 0.24 & 0.24 \\
\cline { 2 - 12 } & 集合 & 0.76 & 0.76 & 0.76 & 0.76 & 0.76 & 0.76 & 0.76 & 0.76 & 0.76 & 0.76 \\
\hline
\end{tabular}

表-5 将来産業出荷額変化率の設定 ( - )

\begin{tabular}{c|c|c|c|c|c|c|c|c|c|c|c}
\hline 産業 & 2005 & 2010 & 2015 & 2020 & 2025 & 2030 & 2035 & 2040 & 2045 & 2050 & 備考 \\
\hline 第1次 & 1.000 & 1.000 & 1.000 & 1.000 & 1.000 & 1.000 & 1.000 & 1.000 & 1.000 & 1.000 & 現状から変化なし \\
\hline 第2次 & 0.986 & 0.986 & 0.986 & 0.986 & 0.986 & 0.986 & 0.986 & 0.986 & 0.986 & 0.986 & 2002 年 2006年の幾何平均が続く \\
\hline 第3次 & 1.008 & 1.008 & 1.008 & 1.008 & 1.010 & 1.010 & 1.006 & 1.006 & 1.000 & 1.000 & $\begin{array}{l}2020 \text { 年までは2002年 2006年の } \\
\text { 何平均, 2020年以降は日本経済 } \\
\text { 研究センターの長期予測の值を利用 }\end{array}$ \\
\hline
\end{tabular}




\section{a) 現状用途地域推定サブモデル}

メッシュごとに現状のどの都市計画用途地域（12類 型）に分類されるかを推定するモデルである．250mメ ッシュでは，大規模開発地区を除き 1 メシュ内に複数 の用途地域が混在する場合が大多数である. そこで本研 究では, 大阪市土地利用現況調查 ${ }^{9}$ 上り得られる小分類 代表用途をベースに各メッシュをスクリーニングし，代 表の用途地域を設定するモデルを開発した．モデルの概 要を図-4に，土地利用現況調查で整備される代表用途の 小分類を表-6に示す．これを基に，1，2にあたるメッシ 工が住居系用途地域，3，4が商業系用途地域，5，6が工 業系用途地域に分類されるという考え方を基本とした. 住居系用途地域の選定では，メッシュごとに住宅平均階 数を計算し, 階数が高いメッシュは中高層住居専用地域 とした. また，住居以外にも複数の用途が建設可能な第
1種，第2種住居地域の選定では，第2種住居地域に建設 できる宿泊用途の床面積を指標として分類を行った７ の複合型メッシュについては，住居系・業務系・工業系 それぞれの床面積割合に応じて, 準工業地域・準住居地 域・近隣商業地域に分類した。

表-6 大阪市土地利用現況調査における代表用途分類

\begin{tabular}{c|l|l}
\hline 番号 & 代表用途名称 & \multicolumn{1}{|c}{$\begin{array}{c}\text { 分類ルール } \\
\text { (床面積割合) }\end{array}$} \\
\hline \hline 1 & 住居専用型 & 住居系が $80 \%$ 以上 \\
\hline 2 & 住居型 & 住居系が $50 \%$ 以上 \\
\hline 3 & 商業専用型 & 商業系が $40 \%$ 以上 \\
\hline 4 & 商業型 & 商業系が $30 \%$ 以上 \\
\hline 5 & 工業専用型 & 工業系が $90 \%$ 以上 \\
\hline 6 & 工業型 & 工業系が $80 \%$ 以上 \\
\hline 7 & 複合型 & 上記以外 \\
\hline
\end{tabular}

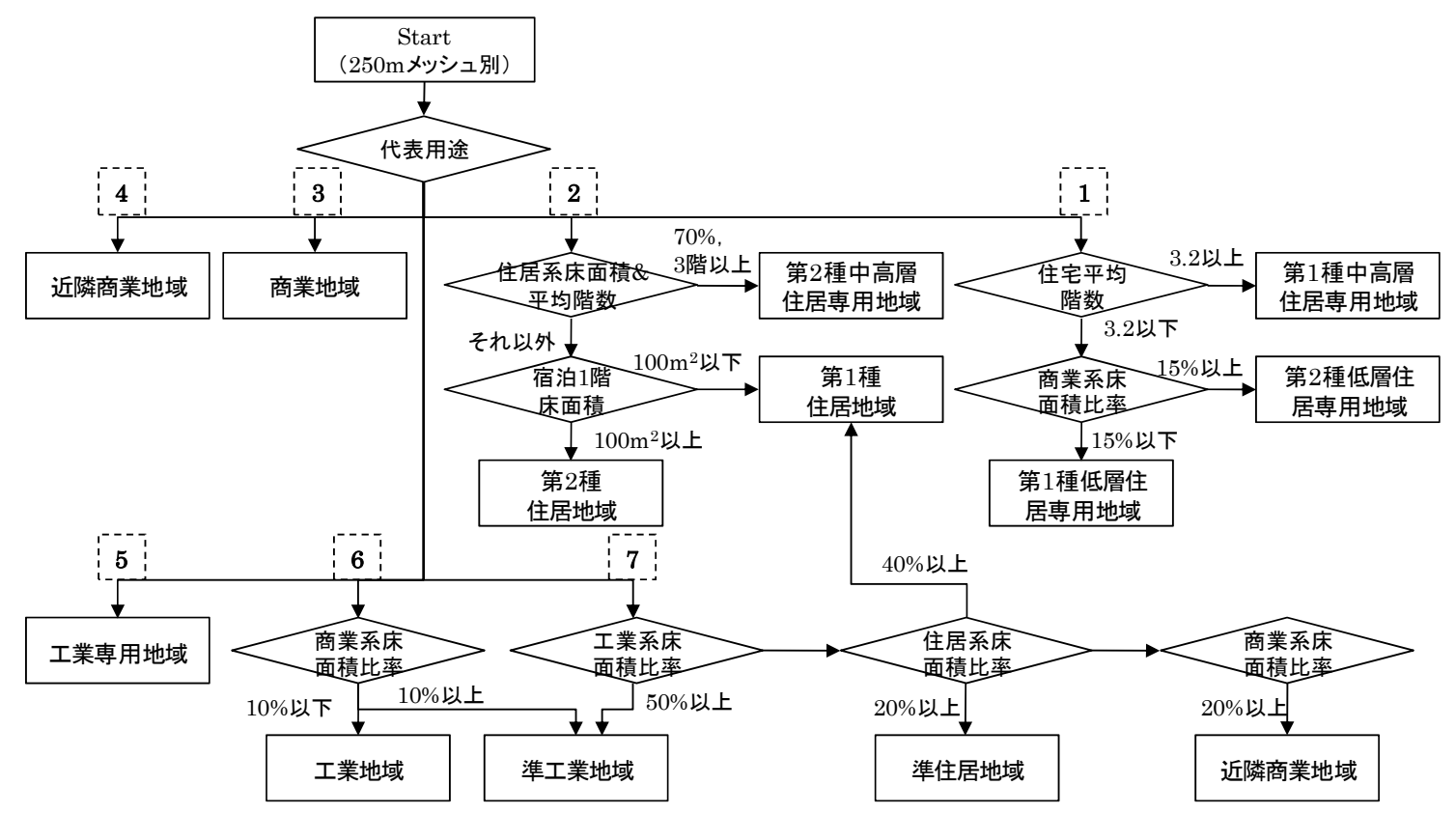

図-4 現状用途地域推定システム

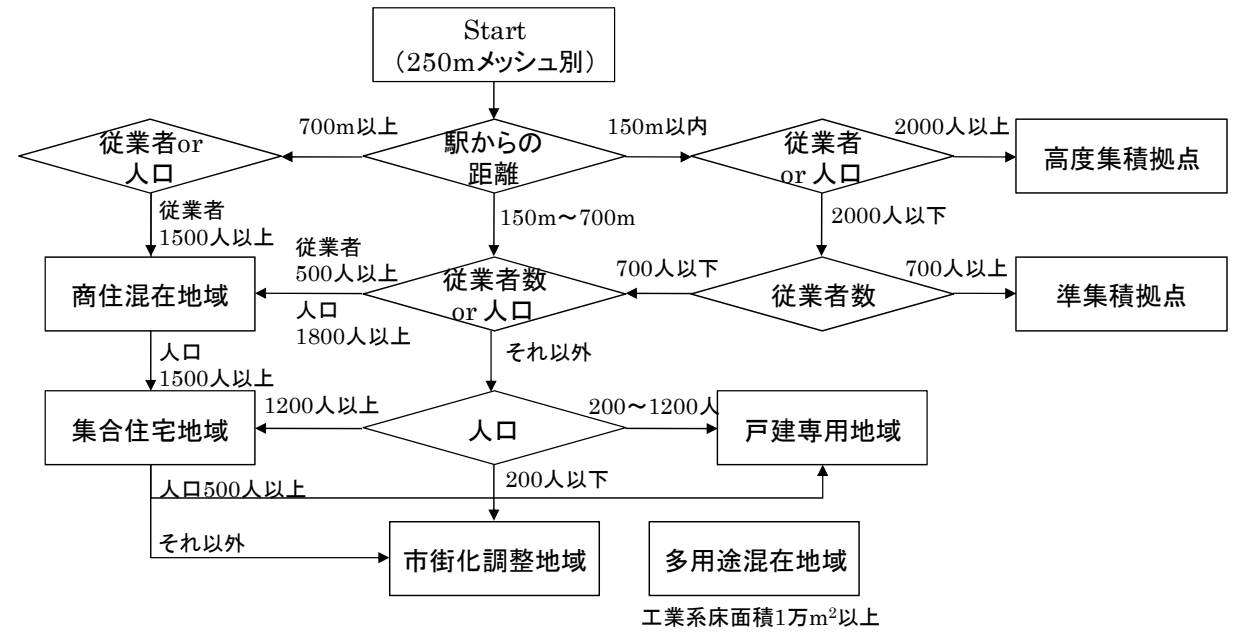

図-5 拠点選定システム 


\section{b) 拠点選定サブモデル}

どのメッシュを集約拠点とするか選定するとともに， 集約拠点と選定されなかった地域も，新規都市計画用途 地域の区分で分類を行うモデルである（図-5）。

まず駅からの距離を指標として第1段階のスクリーニ ングを行う。駅から近い場所はできるだけ高度に利用す る地域に指定する．第2，第3段階では，国勢調査や事業 所・企業統計より得られる人口と従業者数を指標として, 現状において集約度が高い地域も適切に利用していくと 設定した．工業系の床面積が多いメッシュは多用途混在 地域と設定した。一方，駅から遠く，現状の集積が少な いメッシュは市街化調整地域とし，撤退候補地とした。

今回は大阪市でモデルを適用寸ることを念頭に，大阪 府都市計画マスタープラン ${ }^{15)}$ 等を参考として上述の3つ の分類指標を用いたが，他都市で評価する場合には，そ れぞれの都市の実情に見合った指標の選択が可能である。

\section{（6）建設床面積算出モデル}

更新床面積の1階床面積集計を以下では開発可能床面 積と呼び，新たな建物が建設可能な土地の面積とする. この開発可能床面積を，式(2)のように建蔽率で除し， 容積率を乗じたものを受入可能床面積とする．この受入 可能床面積は2050年まで5年ごとの各年代において各々 のメッシュの受け入れ可能な床面積の上限值であり, メ ッシュ単位で集計し，これを超える床面積は受け入れ不 可と設定して建物が新築されることはないとする。 なお, 建蔽率は，集約拠点である2地域は80\%，それ以外の地 区は60\%と設定した.

受入可能床面積=開発可能床面積(更新1階床面積) $\div$ 建蔽率 $\times$ 容積率

次いで，各街区において新たに建設される建物の延べ 床面積の計算には式(3)を用いた。将来床面積需要推計 モデルより算出される床面積需要から5年ごとの床面積 増減量を計算する。 この床面積増減量に更新床面積を加 えることで，年代ごとに新しく建設すべき床面積が算出 される。

新規建設床面積=更新床面積 $+\Delta$ 床面積需要増減量 (3)

\section{(7) 床面積配分モデル}

\section{a) モデルの概要と建設優先順位の設定}

都市全体で算出された新規建設床面積が，受入可能床 面積を超えない範囲で各メッシュの着工床面積に年代別 に配分していくモデル構成とした.

まず，表-7に示すように建物用途別に建設される地域 の優先順位を設定する. 集約型都市一段階的に誘導して いくために，各年代において可能な限り集積拠点におい
て新規建設が行われるように設定した。 このように，大 阪市全体を対象に250mメッシュ単位で，各年代に建設 される床面積を配分していくが，行政・文教・病院の3 用途については公共性の高い施設であり, その機能上， 適切に分散して立地する必要があることから，本研究で は場所を変更せずに建て替えると設定する.

以上のルールに基づき，各年代における新規建設床面 積を各地域に配分し，用途別に着工床面積を算出する. 着工床面積とは，各メッシュにおいて実際に新築される 床面積である. ただし高度集積拠点や準集積拠点では, 開発が行われる最低1階床面積制限と商住混在比率を設 定し，これらの条件で着工床面積を算出する.

\section{b) 着工床面積の計算手順}

本モデルでは，可能な限り集積拠点において建物を建 設する設定を行うため, 集積地域から順に着工床面積の 計算を行う。ただし，非現実的な設定を避けるため，集 積拠点では容積率の制限の他に，「開発可能1階床面 積」と「商住混在比率」に制限を設ける. 以上の条件を 考慮した上で床面積を配分し, 着工床面積を算出する計 算手順のフローを図-6に示寸．また，都市構造ケース別 の各種パラメータ設定值を表-8とした.

$\bigcirc$ 高度集積拠点（商業地域）の計算手順

・開発可能1階床面積 $>7,500 \mathrm{~m}^{2}$ なら開発する

- 開発可能1階床面積 $\leqq 7,500 \mathrm{~m}^{2}$ の場合は，その分の1階 床面積は次期（5年後）に持ち越し

・開発を行う場合，受入可能床面積（式(2)）を算出

表-7 新規建設地域の優先順位設定

\begin{tabular}{|c|c|c|c|c|c|c|c|c|}
\hline \multicolumn{2}{|c|}{ 建て替え前用途 } & \multicolumn{7}{|c|}{ 新規建設地域 (用途別) と建設優先順位 } \\
\hline \multirow[b]{2}{*}{ ケース } & \multirow[b]{2}{*}{ 用途 } & \multicolumn{2}{|c|}{ 集積拠点 } & \multicolumn{5}{|c|}{ 拠点以外の地域 } \\
\hline & & $\begin{array}{l}\text { 高度 } \\
\text { 集積 }\end{array}$ & $\begin{array}{l}\text { 準集 } \\
\text { 積 }\end{array}$ & $\begin{array}{l}\text { 商住 } \\
\text { 混在 }\end{array}$ & $\begin{array}{l}\text { 戸建 } \\
\text { 専用 }\end{array}$ & $\begin{array}{l}\text { 集合 } \\
\text { 住宅 }\end{array}$ & $\begin{array}{c}\text { 多用途 } \\
\text { 混在 }\end{array}$ & $\begin{array}{c}\text { 市街化 } \\
\text { 調整 }\end{array}$ \\
\hline \multirow{5}{*}{$\begin{array}{c}\text { 多極高度 } \\
\text { 集約 }\end{array}$} & 戸建 & $x$ & $x$ & $x$ & () & $x$ & 0 & $\Delta$ \\
\hline & 集合 & (2) & $\mathrm{O}$ & $\triangle$ & $x$ & $\Delta$ & $\diamond$ & $x$ \\
\hline & 業務 & \multirow{3}{*}{ (?) } & \multirow{3}{*}{ O } & \multirow{3}{*}{$\triangle$} & \multirow{3}{*}{$x$} & \multirow{3}{*}{$x$} & \multirow{3}{*}{$\times$} & \multirow{3}{*}{$x$} \\
\hline & 商業 & & & & & & & \\
\hline & 宿泊 & & & & & & & \\
\hline \multirow[b]{2}{*}{ ケース } & \multirow[b]{2}{*}{ 用途 } & \multicolumn{2}{|c|}{ 集積拠点 } & \multicolumn{5}{|c|}{ 拠点以外の地域 } \\
\hline & & 商業 & $\begin{array}{l}\text { 近隣 } \\
\text { 商業 }\end{array}$ & $\begin{array}{c}\text { 第1種 } \\
\text { 住居 } \\
\text { 第2種 } \\
\text { 住居 } \\
\text { 準住 } \\
\text { 居 }\end{array}$ & $\begin{array}{c}\text { 第1種 } \\
\text { 低層 } \\
\text { 住居 } \\
\text { 第2種 } \\
\text { 低層 } \\
\text { 住居 }\end{array}$ & $\begin{array}{c}\text { 第1種 } \\
\text { 高層 } \\
\text { 住居 } \\
\text { 第2種 } \\
\text { 高層 } \\
\text { 住居 }\end{array}$ & $\begin{array}{c}\text { 準工業 } \\
\text { 工業 } \\
\text { 工業専 } \\
\text { 用 }\end{array}$ & $\begin{array}{c}\text { 市街化 } \\
\text { 調整 }\end{array}$ \\
\hline \multirow{5}{*}{$\begin{array}{c}\text { 多極普通 } \\
\text { 集約 }\end{array}$} & 戸建 & $x$ & $x$ & $\Delta$ & () & 0 & $\Delta$ & $\triangle$ \\
\hline & 集合 & (2) & $\mathrm{O}$ & $\triangle$ & $x$ & $\Delta$ & $\diamond$ & $x$ \\
\hline & 業務 & \multirow{3}{*}{ (?) } & \multirow{3}{*}{ O } & \multirow{3}{*}{$\triangle$} & \multirow{3}{*}{$x$} & \multirow{3}{*}{$x$} & \multirow{2}{*}{$\boldsymbol{\Delta}$} & \multirow{3}{*}{$x$} \\
\hline & 商業 & & & & & & & \\
\hline & 宿泊 & & & & & & $x$ & \\
\hline 傾向延長 & 全て & \multicolumn{7}{|c|}{ 同じ場所で建て替え } \\
\hline \multicolumn{2}{|c|}{ 行政 } & \multirow{3}{*}{\multicolumn{7}{|c|}{ 場所の変更なし }} \\
\hline & & & & & & & \\
\hline \multicolumn{2}{|c|}{ 病院 } & & & & & & & \\
\hline
\end{tabular}

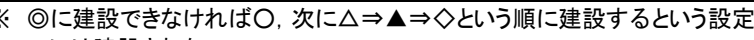
メには建設されない 
- 大阪市全体の新規建設床面積を受入可能床面積の範囲 内で配分していく

・配分順序は, 駅からの距離が近いメッシュ順

・駅からの距離が同じ場合は, 開発可能1階床面積が多

いメッシュ順

-商住混在比率=住宅（集合）: 商業 : 業務 $=50: 15$ :

35で着工床面積としていく

・商住混在比率を満たしながら順番に各メッシュを開発 （着工床面積を決定）していく

・受入可能床面積 $=0$ となれば，準集積拠点の計算へ

・ また, 受入可能床面積 $>0$ であっても, 商住混在比率 を満たすための新規建設床面積が0であれば，商住混在 比率を崩して開発は行なわず，準集積拠点以降で着工さ

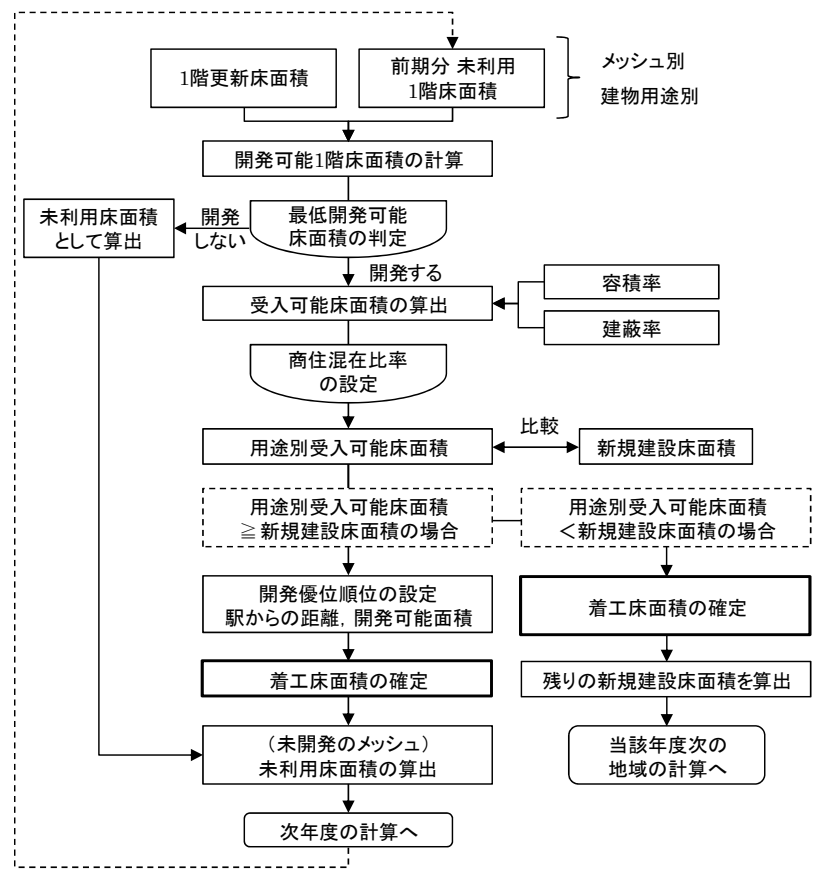

図-6＼cjkstart床面積配分モデルの計算手順

表-8 床面積配分モデルにおけるパラメータ設定值

\begin{tabular}{|c|c|c|c|}
\hline \multirow{2}{*}{ 用途地域別 } & \multirow{2}{*}{ 設定項目 } & \multicolumn{2}{|c|}{ 将来都市構造ケース } \\
\hline & & 多極高度集約 & 多極普通集約 \\
\hline \multirow{4}{*}{$\begin{array}{c}\text { 高度集積 } \\
\text { 拠点 } \\
\text { (商業地域) }\end{array}$} & 容積率 $(\%)$ & 1000 & 600 \\
\hline & 建蔽率(\%) & 80 & 80 \\
\hline & $\begin{array}{c}\text { 最低開発1階 } \\
\text { 床面積 }\left(\mathrm{m}^{2}\right)\end{array}$ & 7500 & 7500 \\
\hline & 商住混在比率 & $50: 20: 30$ & $50: 20: 30$ \\
\hline \multirow{4}{*}{$\begin{array}{l}\text { 準集積 } \\
\text { 拠点 } \\
\text { （近隣商業 } \\
\text { 地域） }\end{array}$} & 容積率 $(\%)$ & 800 & 400 \\
\hline & 建蔽率 $(\%)$ & 80 & 80 \\
\hline & $\begin{array}{c}\text { 最低開発1階 } \\
\text { 床面積 }\left(\mathrm{m}^{2}\right)\end{array}$ & 5000 & 5000 \\
\hline & 商住混在比率 & $60: 15: 35$ & $60: 15: 35$ \\
\hline \multirow{4}{*}{$\begin{array}{l}\text { 商住混在 } \\
\text { 地域 } \\
\text { (準住居系 } \\
\text { 地域) }\end{array}$} & 容積率 $(\%)$ & 300 & 300 \\
\hline & 建蔽率 $(\%)$ & 60 & 60 \\
\hline & $\begin{array}{c}\text { 最低開発1階 } \\
\text { 床面積 }\left(\mathrm{m}^{2}\right)\end{array}$ & なし & なし \\
\hline & 商住混在比率 & なし & なし \\
\hline
\end{tabular}

れるとする

・その場合に使用されなかった開発可能1階床面積は次 年度へ持ち越し

・次期以降の計算では，その期間に更新される1階床面 積に加え, 前期に利用されなかった開発可能1階床面積 分を合わせて，その時期の開発可能床面積とする

$\bigcirc$ 準集積拠点（近隣商業地域）の計算手順

・高度集積拠点の計算手順と同様である

- 開発可能1階床面積. 商住混在比率の設定值が表-8に 示すよう異なる

・ただし，一極集中ケースにおける床面積配分では，拠 点において可能な限り多くの床面積を受け入れる設定と するため, 商住混在比率は設定せず, 容積率の制限を超 えない範囲で床面積を受け入れる

○商住混在地域 (準住居系地域) の計算手順

- 高度集積拠点・準集積拠点とは異なり, 開発最低1階 床面積・商住混在比率の制限なしに開発を行う。

・受入可能床面積が0となるまで開発を行う.

・新規建設床面積<受入可能床面積となった場合には, 駅から近いメッシュ順に開発を行い, 開発されなかった メッシュは, 次期以降に開発されるとする.

$\bigcirc$ 集合住宅地域・ 戸建専用地域（第1種・第2種高層・ 低層住居専用地域）の計算手順

・以上の地域において床面積配分を行い，着工されてい ない新規建設床面積を集合・戸建別に受け入れる

多用途混在地域・市街化調整地域（その他工業系地 域) の計算手順

・これらの地域はできる限り開発は行わない

・余剩となる床面積が存在する場合のみ，新たに着工す る.

なお，傾向延長ケースでは床面積の移動は行わず，同 じ場所で建物更新が実施された場合を想定する. 将来の 床面積需要の変化は他ケースと同様に考慮し, 各年代の 着工床面積を用途別に算出した.

\section{3. 省エネルギーシステム導入評価モデルの構築}

\section{(1) 省エネルギーシステムの設定}

低炭素都市形成のため省エネルギー対策として，(1) 熱利用効率の向上，(2)太陽光発電等の再生可能エネル ギーの大幅導入，(3)省エネ機器効率改善と普及, の3点 が挙げられる. (1)では, 熱源を個別化するか, 集中化 するか, 熱需要をヒートポンプシステム（以下， HP シ ステム) で補うか，コージェネレーションシステム（以 下，CGS）で補うかが主として論じられている1), 16)。 た，(2)では，特に都市部において大幅導入が期待され る太陽光発電の不安定な出力の変動調整が課題とされて 

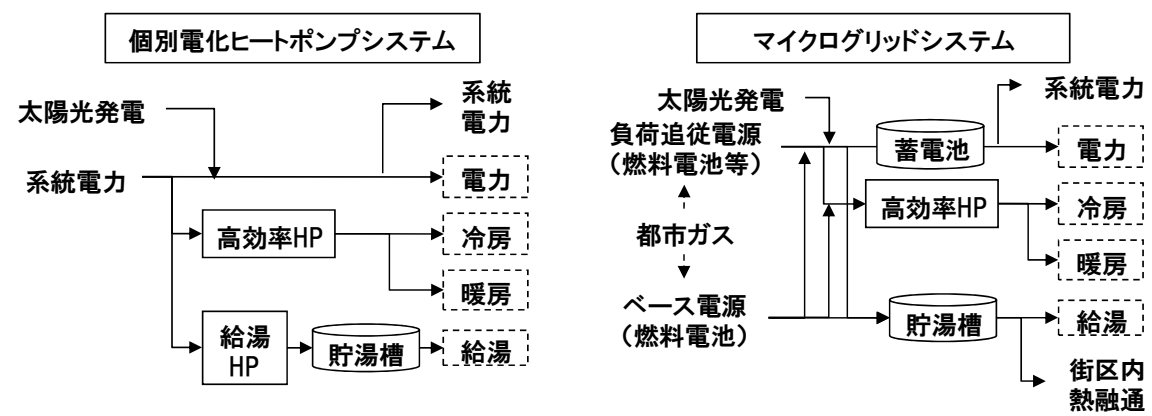

図-7＼cjkstart省エネルギーシステムのフロー

おり ${ }^{5}$ ，その調整方法として，系統電力と連携して対応 する方法と，地域内でグリッドを形成する方法の 2 点が 主として考えられる.

したがって, 本研究では, 熱利用効率に関する論点と 自然エネルギーの大幅導入の論点に対する特徽的な2つ の省エネルギーシステムを取り上げる，具体的には，個 別電化ヒートポンプシステム (略称 : 個別HP) と，マ イクログリッドシステム（略称：MG）の2つのエネル ギーシステムを設定した．図-7に両システムの概要図を 示す．個別電化HPシステムは，建物個別にHPシステム を導入し全熱需要を電力で賄う全電化方式であり，太陽 光発電の余剩電力は系統電力へ売電するシステムである. MGシステムは, 街区内でエネルギーシステムを共有す る燃料電池を用いたコージェネレーションシステム

（CGS）で，太陽光発電の余剩電力と発電排熱の両方を 街区内で融通するシステムである，年間の需要変動が激 しい冷暖房需要は, 両システムともに高効率HPで賄わ れる，給湯需要については，MGシステムにおいてCGS の発電排熱が利用されるとし, 建物単位で余剩の温水が 発生する場合は, 温水を街区内で融通させた. よって, 本研究における街区内での熱融通は，給湯熱需要に対す るCGSからの温熱融通を対象とし，冷熱の融通は扱わな い，また，両技術が選択的に導入された場合の $\mathrm{CO}_{2}$ 削減 量を併せて推計することにより，都市に存在する建物の 状況に対応したエネルギ一管理のあり方を評価・検討で きるモデルを構築した．本研究では，太陽光発電導入に よる電力融通や熱融通などのエネルギー需給バランスを 計算するため, 1 年を夏期・中間期・冬期の3時期に分類 し，時期ごとに1時間間隔で1日のエネルギー消費量を算 定可能なモデルを構築する. 以下に, 省エネルギーシス テムの詳細を述べる.

\section{a) 個別電化ヒートポンプシステム}

・冷暖房用の空調HPシステムは, 業務系建物にはビル マルチ式空調システム，住居系建物には冷暖房兼用エア コンを建物個別に設置する．給湯用HPシステムは，業 務系・住居系建物ともに自然冷媒 $\left(\mathrm{CO}_{2}\right) \mathrm{HP}$ 給湯機を設 置する. 冷暖房用・給湯用HPともに部分負荷損失はな いものとする.
・給湯HPは午前0時〜朝6時に1日の必要熱量を生成し,

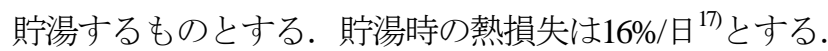
·給湯HPは外気温とともにCOPが変化するものとし, 空調HPは外気温によらず一定とする.

・空調HP, 給湯HPともに年代とともにCOP值が向上す るものとする.

·電力負荷に関しては，太陽光発電で生成した電力で賄 いきれない電力負荷については，系統電力から購入する. ·電力負荷を超える太陽光発電の生成電力は, 余剩電力 として系統電力へ売電可能とするが，逆潮流できる量に 制限を与え，制限を越える分は廃棄されると設定する.

·系統電力側の電源構成, 発電効率は2050年まで変化し ないものと仮定する.

b) マイクログリッドシステム

本システムは，極力一定出力でエネルギー効率が高い 状態で運転するべース電源, 負荷に合わせて出力を変動 寸る負荷追従電源, 変動電源（太陽光発電）, 蓄電池, 及び制御系機器で構成される.

・ ベース電源は，業務系床面積が多い街区には発電効率 が高く, 出力変動に適さない固体酸化物型燃料電池（以 下SOFC） とガスタービンのコンバインドサイクルを， 給湯負荷の大きい集合住宅および戸建専用地域には, SOFCと比較して排熱回収効率が大きい固体高分子型燃 料電池（以下PEFC）を導入する.

- 負荷追従電源は，商住用途が混在する地域（集積拠 点・商業地域など）には負荷追従性に優れ，発電効率が 高いガスエンジンを，集合住宅街区・戸建専用街区には ベース電源と同じく, 発電時の部分負荷損失がない PEFCを導入する.

·負荷追従電源には部分負荷損失を考慮する. ガスエン ジンは部分負荷運転時に発電効率が低下し，PEFCは部 分負荷運転時に排熱回収効率が低下寸るものとする.

- 燃料電池の発電効率は年代とともに向上するものとし, ガスエンジンの発電効率は現状と変化せず一定とする.

·太陽光発電の変動を調整するために, 電力負荷に合わ せて運転し，熱供給は結果として得られる排熱を利用す る電主熱従方式を選択する.

・年間の出力変動が大きい冷暖房負荷に関しては, 建物 
個別に設置する高効率HPで賄い，給湯用熱負荷のみ分 散型電源の排熱を街区内で融通利用する。熱負荷に対し て，排熱が不足する場合はガスボイラを用いて生成する。 · 排熱の余剩分は貯湯し，1日の別の時間帯に利用し, 余剩分は廃棄されるとする．貯湯時の熱損失は $16 \% /$ 日 $^{177}$ とする.

・熱の配管輸送に伴う損失は $5 \%{ }^{18)}$ とし，熱供給面積によ らず一定とする.

・売電制約を超える太陽光発電の余剩電力は可能な限り 蓄電し, 電力負荷の大きい時間帯に街区内で融通利用し, 利用しきれない分は廃棄されるものとする.

・蓄電池は充放電効率が高く, 大規模化が容易なNaS電 池を用い，夜間のベース電源・昼間の太陽光発電による 余剩電力を可能な限り蓄電し街区内で融通する。 なお, $\mathrm{NaS}$ 電池の充放電効率は $\left(87 \%{ }^{19}\right.$ とした.

\section{(2) 導入評価ケースの設定}

本研究では，大阪市全体に個別電化HPシステム，マ イクログリッドシステムのいずれかが導入されるケース と, 用途別建物構成やエネルギ一消費構造を踏まえ, 両 システムのうち $\mathrm{CO}_{2}$ 排出量の観点から優位なシステムが 選択的に導入される選択的導入ケースを評価対象とした.

\section{（3）エネルギ一消費・負荷原単位の算出}

大阪市を対象に，現状における床面積（世帯）あたり
のエネルギー消費原単位とエネルギー負荷原単位を算出 する.まず，既往文献(20)で用いられているエネルギー消 費原単位に大阪市の用途別延床面積を乗じ，大阪市全体 のエネルギー消費推計值を算出したのち，大阪市のエネ ルギー消費量統計值に近づくように補正したものを本研 究におけるエネルギー消費原単位とした. 次に, 現状の 機器効率を用途別・燃料種別に設定 ${ }^{27} し$ ，これにエネル ギー消費原単位を乗じることで，エネルギ一負荷原単位 を算出した.

\section{(4) 個別機器·建物断熱性能の技術係数の設定}

建設される建物に対して各年代の技術効率・導入率を 有する個別機器・断熱仕様が導入されるとした。 そこで, 既往研究を参考に, 表-9に示寸照明システム ${ }^{21)}$ ・パソコ ンなどのOA機器22,23) ・ 高効率 $\mathrm{HP}^{24}$ ・太陽光発電システム の機器効率 ${ }^{24}$ と蓄電池の導入率 ${ }^{25}$, 高断熱建物の普及率 を設定した. また，部分負荷損失を考慮したガスエンジ ン及び燃料電池の発電効率・熱回収効率20,27についても, 表-10のように設定した.

(5) 個別電化ヒートポンプシステム導入評価モデル a) 個別対策導入エネルギ一負荷算定モデル

個別機器の省エネルギー対策は, 高効率な機器が採用 されていくと仮定し, 照明システムとOA機器について のエネルギー消費原単位の変化を図-8のように設定した.
表-9 省エネルギー技術効率・導入率推移の設定

\begin{tabular}{|c|c|c|c|c|c|c|c|c|}
\hline \multirow{2}{*}{\multicolumn{3}{|c|}{$\begin{array}{c}\text { 機器 } \\
\text { (単位, 設定条件) }\end{array}$}} & \multirow{2}{*}{ 現状 } & \multicolumn{5}{|c|}{ 将来の設定値 } \\
\hline & & & & 2010年 & 2020年 & 2030年 & 2040年 & 2050年 \\
\hline \multicolumn{3}{|c|}{$\begin{array}{c}\text { 建物の断熱性能 } \\
\text { (基準の建物が建設される割合) }\end{array}$} & - & \multicolumn{2}{|c|}{$\begin{array}{c}\text { 新基準: 次世代= } \\
50 \%: 50 \%\end{array}$} & \multicolumn{3}{|c|}{ 次世代 $=100 \%$} \\
\hline \multicolumn{3}{|c|}{ 照明システム $[\mathrm{lm} / \mathrm{W}]$} & 60 & 100 & \multicolumn{4}{|c|}{150} \\
\hline \multicolumn{3}{|c|}{$\begin{array}{c}\text { OA機器 } \\
\text { (現状を1とした際の比率) }\end{array}$} & 1 & 1 & $3 / 4$ & \multicolumn{3}{|c|}{$1 / 2$} \\
\hline \multirow{5}{*}{$\begin{array}{l}\text { 高効率HP } \\
\text { (COP) }\end{array}$} & \multirow{2}{*}{$\begin{array}{l}\text { 冷暖房 } \\
\text { エアコン }\end{array}$} & 冷房 & 4.50 & 4.50 & 5.45 & 6.36 & \multicolumn{2}{|c|}{7.27} \\
\hline & & 暖房 & 5.00 & 5.00 & 6.00 & 7.00 & \multicolumn{2}{|c|}{8.00} \\
\hline & \multirow{2}{*}{$\begin{array}{l}\text { ビルマルチ } \\
\text { 式空調 }\end{array}$} & 冷房 & 2.60 & 3.30 & 3.60 & \multicolumn{3}{|c|}{4.00} \\
\hline & & 暖房 & 3.10 & 4.00 & 4.50 & \multicolumn{3}{|c|}{5.00} \\
\hline & \multicolumn{2}{|c|}{ 給湯ヒートポンプ } & 3.00 & 3.00 & 3.50 & 4.00 & 4.50 & 5.00 \\
\hline \multicolumn{3}{|c|}{$\begin{array}{c}\text { 蓄電池 } \\
\text { (導入率[\%]) }\end{array}$} & $6 \%$ & $6 \%$ & $8 \%$ & \multicolumn{2}{|c|}{$12 \%$} & $16 \%$ \\
\hline \multicolumn{3}{|c|}{$\begin{array}{c}\text { 太陽光発電システム } \\
\text { (モジュール変換効率[\%]) }\end{array}$} & $10.0 \%$ & $10.0 \%$ & $12.5 \%$ & $15.0 \%$ & $17.5 \%$ & $20.0 \%$ \\
\hline
\end{tabular}

表-10 ガスエンジン・燃料電池の部分負荷率と機器効率の年代別設定

\begin{tabular}{|c|c|c|c|c|c|c|c|c|c|c|}
\hline \multirow{2}{*}{\multicolumn{2}{|c|}{ 機器 }} & \multirow{2}{*}{\multicolumn{4}{|c|}{ ガスエンジン }} & \multicolumn{5}{|c|}{ 定置用燃料電池 } \\
\hline & & & & & & & & & & SOFC \\
\hline 負荷 & ）率 & $0 \sim 25$ & $25 \sim 50$ & $50 \sim 75$ & $75 \sim 100$ & $0 \sim 25$ & $25 \sim 50$ & $50 \sim 75$ & $75 \sim 100$ & - \\
\hline \multirow{5}{*}{ 発電 } & $\begin{array}{l}2010 \text { 年 } \\
\end{array}$ & \multirow{5}{*}{0.315} & \multirow{5}{*}{0.387} & \multirow{5}{*}{0.432} & \multirow{5}{*}{0.450} & "0.360 & (20.360 & $\begin{array}{l}0.360 \\
\end{array}$ & 0.360 & (20.500 \\
\hline & 2020 年 & & & & & 0.370 & 0.370 & 0.370 & 0.370 & 0.520 \\
\hline & 2030年 & & & & & 0.380 & 0.380 & 0.380 & 0.380 & 0.540 \\
\hline & 2040 年 & & & & & 0.390 & 0.390 & 0.390 & 0.390 & 0.560 \\
\hline & 2050年 & & & & & 0.400 & 0.400 & 0.400 & 0.400 & 0.580 \\
\hline \multirow{5}{*}{ 熱回収 } & 2010 年 & \multirow{5}{*}{0.405} & \multirow{5}{*}{0.351} & \multirow{5}{*}{0.324} & \multirow{5}{*}{0.315} & \multirow{5}{*}{0.342} & \multirow{5}{*}{0.378} & \multirow{5}{*}{0.414} & \multirow{5}{*}{0.450} & 0.240 \\
\hline & 2020 年 & & & & & & & & & 0.230 \\
\hline & 2030年 & & & & & & & & & 0.220 \\
\hline & 2040 年 & & & & & & & & & 0.210 \\
\hline & 2050年 & & & & & & & & & 0.200 \\
\hline
\end{tabular}

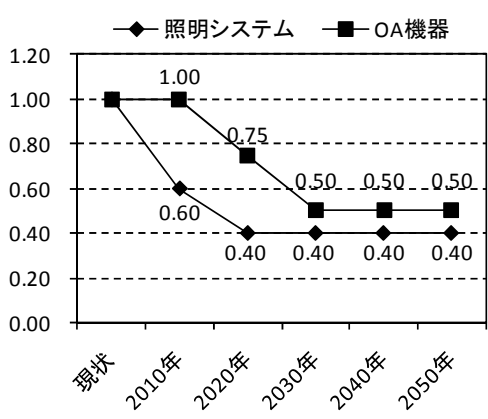

図-8 個別機器効率向上による エネルギー消費変化率

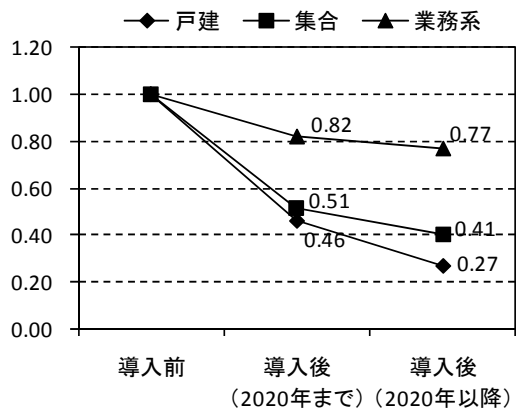

図-9断熱性能向上による エネルギー消費変化率 
建物の断熱性能向上対策は，2020年までは新基準の建物 が50\%，次世代基準の建物が50\%の割合で新設され， 2020年以降は次世代基準の建物に100\%建て替わると設 定し, 現状ストックの断熱性能基準比率と比較すること で暖房負荷原単位の減少率を図-9のように算出した。こ のとき，断熱性能の従来型に対する削減率は，業務系建 物に関しては文献 ${ }^{28)}$ の值を, 集合住宅, 戸建住宅に関し ては文献 ${ }^{29)}$ の地域区分別の值のうち, 大阪市が属するIV 地域における值を用いた。 2000年の断熱基準別ストック 床面積比は, 文献 ${ }^{300}$ の全国における值を参照した.

\section{b) HP導入後エネルギ一消費原単位算定モデル}

空調HPおよび給湯HP導入後のエネルギー消費原単位 を算出する，空調HPについては，表のCOP值でエネル ギ一負荷原単位を除することで, 空調HP用の電力消費 原単位が算出される. 給湯HPは作動時間帯を午前0時〜 6時に設定する．そこで，まず年間のエネルギ一負荷原 単位に月別の負荷パターン200,31)を乗じることで，月別エ ネルギー負荷原単位を計算する. 次に, 月別のエネルギ 一負荷原単位に，3時期別（夏期6９月・中間期4,5,10,11 月・冬期12３月）の時刻別負荷パターン20,31)を乗じ，日 数で除することで時刻別エネルギー負荷原単位を算出し た. ここで，午前0～6時の給湯HP用電力消費量は，貯 湯による熱損失（16\%/日）を踏まえて式(4)で算出した.

給湯用電力エネルギー消費 $[\mathrm{MJ} / \mathrm{h}]=$

1 日の給湯負荷 $[\mathrm{MJ} /$ 日 $] \div$ 給湯HPCOP $\div 7 \times 1.16$

これに, 先に求めた空調HP用の電力消費量と照明・動 力分の電力消費を加えることで, $\mathrm{HP}$ 導入後の用途別 ・ 月別・時刻別のエネルギー消費原単位を算出した.

\section{c) 太陽光発電導入評価モデル}

本モデルは，太陽光発電の出力を設定し，系統電源へ の逆潮流を考慮した太陽光発電の利用可能量を算出する モデルである。

まず，高橋220の方法を参考に，式(5)を用いて，新築さ れる建物の屋根に設置した太陽光発電の月別・時刻別の 出力を天候別 (晴れ, 曇り, 雨) - 月別に算出した.

$$
\text { Out }=H_{A}(h) \times \eta \times S \times \eta p c \times K p t \times K
$$

Out : 太陽光発電出力 [M]

$H_{A}(h)$ : 時間hにおける斜面日射量 $\left[\mathrm{MJ} / \mathrm{m}^{2}\right]$

$\eta:$ モジュール変換効率

$S:$ 設置面積 $\left[\mathrm{m}^{2}\right]$

$\eta p c:$ パワーコンディショナー運転効率

$K p t$ : 月別温度補正係数

$K:$ その他システムの出力係数

時刻別の斜面日射量データ $H_{A}(h)$ は, 太陽光発電用標 準気象データ（METPV-3） ${ }^{33)}$ を用いて，大阪市における 時刻別斜面日射量を天候別（3パターン），月別（12パ
ターン），パネル傾斜角別（2ターン）に，計72パター ンの計算を行った. このときの太陽光発電のパネルの向 き(方位角) $170^{\circ}$ とした. また, パネル傾斜角（水平 面に対する角度）は，戸建て住宅では受光量が最大とな る $30^{\circ}$ ，屋根形状が水平の場合が多い集合住宅や業務系 建物は $10^{\circ}$ とした.

太陽光発電パネルに照射する日射量に対するエネルギ 一変換効率を設定する. 本研究では表-9に示したように, 年代別に太陽電池の変換効率を設定し, 現在の変換効率 10\%から，2050年には20\%まで向上するものとした.

太陽光パネルの設置面積は, まず建物屋根面積を算定 し，用途別に設置率を乗じて算出する. 建物屋根面積は 1階床面積と等しいとして算出する. メッシュごとに設 定した容積率と建蔽率より式(6)を用いて計算を行った.

建物屋根面積 $=$ 着工床面積 $\div$ 容積率 $\times$ 建蔽率

これより設置面積は，式(7)を用いて計算する，戸建 住宅における設置率は屋根面積に占める南面の割合 $=0.35$, 集合住宅・業務系建物は, 東京都における $1,000 \mathrm{~m}^{2}$ 以上の建物の屋上緑化基準が30\%以上であること を参考に，設置率 $=0.3$ 用いた。 $\theta$ は，戸建住宅は $30^{\circ} ，$ 集合・業務系建物は $10^{\circ}$ とした.

パネル設置面積 $=$ 建物屋根面積 $\times$ 設置率 $\times 1 \cos \theta$

月別の太陽電池出力の温度補正係数Kpt(h)は式(8)を, 月別の平均気温 $\left({ }^{\circ} \mathrm{C}\right) \mathrm{Tm}(\mathrm{m})$ は大阪市の 2000 年における 平均気温データ ${ }^{34}$ より表-11の值を用いた。 $\Delta T(m)$ は太陽 電池動作時の温度上昇幅 $\left({ }^{\circ} \mathrm{C}\right)$ であり，5〜10月は $15^{\circ} \mathrm{C}$, 11〜4月は $10^{\circ} \mathrm{C}$ とた.

$$
K p t(h)=1-0.0041 \times(T m(m)+2+\Delta T(m)-25)
$$

系統電源への電力の逆潮流量の設定に関しては, 横井 らクの手法を用い, 太陽光発電が大幅導入された場合の 系統電源に対する売電量 (逆潮流量) の上限に制約をも たせた. 横井らは, 過去の実験・解析において, 地域内 の約 $20 \%$ 以上供給電力が太陽光発電等の分散型電源に 置き換わった場合に問題が生じることが言及しているこ とを踏まえ，太陽光発電の普及率がピーク需要の $20 \%$ に 達するまでは全量が逆潮流可能, ピーク需要の $20 \%$ を超 える分は逆潮流不可能とした. この場合の 1 日の電力負 荷のボトム值に対する太陽光発電の最大出力の比が3.64 であったため, 電力負荷の3.64 倍までは系統電力へ逆潮 流して売電が可能, それ以上は不可能とする.

月別・時刻別・天候別の太陽光発電の1日の利用可能 量は式(9)を用いて求めた.

太陽光発電利用可能量 $=$ 自家消費量 + 売電量 
自家消費量と売電可能量は，エネルギー負荷算定モデル で求めた省エネ技術導入後の建物用途別時刻別の電力負 荷原単位に街区内に新設される建物の床面積を乗じて, 街区内の電力負荷を時刻別に求めた. 次に，街区内の太 陽光発電出力の合計值が電力負荷の合計值を下回る場合 には，全量自家消費量とした．太陽光発電の出力の合計 值が電力負荷の合計值を上回る場合の余剩分は売電量と した. 売電量は式(10)のように求められる. ここで式(11) を用いて，電力負荷の3.64倍を超える余剩電力は，売電 不可能とし, 廃棄されるものとした.

$$
\text { 売電量 }=\text { 太陽光発電出力一電力負荷一余剩電力 }
$$$$
\text { 余剩電力 }=\text { 太陽光発電出力 }- \text { 電力負荷 } \times 3.64
$$

なお，年間の太陽光発電の利用可能量を算定するため には，月別に晴れ・曇り・雨の天候別の日数を設定する 必要がある. そこで, 気象庁ホームページ34 より得られ る気象データから，大阪市の2005年の天候をもとに月別 に天候別の日数を定め，全ての年代においてその值を用 いた. 表-11に大阪市の天候別の日数を示す.

\section{d) $\mathrm{CO}_{2}$ 排出量算定モデル}

個別電化HPシステム導入後のCO 排出量は式(12)を用 いて算出した. 本研究で使用する電力使用による $\mathrm{CO}_{2}$ 排 出原単位は, 全国の1990年から2008年までの全電源原単 位兮を平均した值を用いた（表-12）。

$\mathrm{CO}_{2}$ 排出量 $=($ 電力負荷 - 太陽光発電利用可能量 $) \times$ 電力 $\mathrm{CO}_{2}$ 排出原単位

\section{(6) マイクログリッドシステム導入評価モデル}

\section{a) 個別対策導入エネルギ一負荷算定モデル}

個別電化HPシステム導入評価モデルで用いたものと ほぼ同様である，ただし，個別電化HPシステムでは給 湯負荷をHPで補っていたが，マイクログリッドシステ ムでは燃料電池の排熱およびボイラ生成熱で補うとした。 よって, マイクログリッド導入ケースでは給湯負荷を熱 負荷として別に算出した. 月別・時刻別の給湯負荷原単 位は，(3)節において設定したエネルギー負荷原単位の うちの給湯負荷原単位を用い，これに月別・時刻別の負 荷パターンを乗じて算出した。

\section{b) 太陽光発電導入評価モデル}

個別電化HPシステム導入評価モデルで用いたものと ほぼ同様である.ただし，制約を超える余剩電力のうち，
蓄電池に余裕がある場合は蓄電し, 街区内で融通寸る設 定とする. 売電制約を超え, 蓄電池を用いても融通不可 能な電力は廃棄されるものとした.

\section{c) 発電計画設計モデル}

発電計画設計モデルは，(1)発電計画量の算定，(2)蓄 電池最大出力の設定, (3)ベース電源出力の設定, (4)負 荷追従電源出力の設定の4段階を経て, 蓄電池, ベース 電源, 負荷追従電源の出力量を算出するモデルである.

発電計画量は, 電力負荷を賄うために必要な電力量で あり, 太陽光発電の出力に合わせて変動することから, 月別・時刻別の発電計画量を, 式(13)を用いて晴天時・ 曇天時・雨天時の3パターン算定した.

$$
\text { 発電計画量=電力負荷一太陽光発電出力 }
$$

マイクログリッドシステムへ導入する蓄電池の最大出 力は，式(14)を用いて設定した.

蓄電池最大出力 $=$ 年間最大電力負荷 $\times$ 導入率

ベース電源の出力は，式(15)を用いて設定した．ベー 又電源は年間を通して最大出力で運転する電源なので, 年間の発電計画量の最小值に蓄電池最大出力を加えた值 とした. なお, ベース電源は式(15)で求めた值の半分の 出力能力を持つ発電機を各街区に2基ずつ設置するもの とし，集約拠点・商業系地域においては，全天候時にお いて2基が最大出力で運転，集合住宅地域・戸建専用地 域については, 雨天時は2基が稼㗢, 太陽光発電の出力 により, 昼間の発電計画量が小さくなる晴天時と量天時 については，1基のみ最大出力で運転し，1基は停止する 設定とした.

$$
\begin{gathered}
\text { ベース電源出力 }=\text { 年間発電計画量最小值 }+ \\
\text { 蓄電池最大出力 }
\end{gathered}
$$

月別時刻別の負荷追従電源の出力は, 式(16)を用いて 設定した. 発電計画量を上回るべース電源出力分はNaS 電池に蓄電されるものとし，1日の平均発電計画量を上 回る時間帯に放電されるものとした. NaS電池の充放電 効率は87\%とし, 放電量は各時間帯の発電計画量にもと づいて比例配分した．なお，集合住宅地域・戸建専用地 域の晴天時・曇天時については，逆潮流制約量を超える 太陽光発電の余剩電力が発生している. この余剩電力を

\begin{tabular}{|c|c|c|c|c|c|c|c|c|c|c|c|c|c|}
\hline & 1月 & 2月 & 3月 & 4月 & 5月 & 6月 & 7月 & 8月 & 9月 & 10月 & 11月 & 12月 & 合計 \\
\hline 平均気温 $\left({ }^{\circ} \mathrm{C}\right)$ & 6.2 & 6.1 & 9.2 & 16.2 & 19.5 & 24.9 & 27.5 & 28.7 & 26.1 & 19.8 & 13.7 & 5.9 & - \\
\hline 干候别 晴天日 & 10 & 9 & 12 & 20 & 18 & 12 & 12 & 12 & 10 & 11 & 20 & 17 & 163 \\
\hline 量天日 & 15 & 10 & 7 & 2 & 5 & 10 & 6 & 8 & 12 & 6 & 6 & 8 & 95 \\
\hline 雨天日 & 6 & 9 & 12 & 8 & 8 & 8 & 13 & 11 & 8 & 14 & 4 & 6 & 107 \\
\hline
\end{tabular}
有効活用寸るために，2基のベース電源のうち，1基しか 稼働させていないことで生じる蓄電能力の余力を活用し

表-11 2005年大阪市の平均気温・天候別日数 
て, 売電制約量を超える太陽光発電の余唾電力を蓄電し, 1日の平均発電計画量を上回る時間帯に放電されるもの とした. 集積拠点・商業系地域の負荷追従電源であるガ スエンジン，集合住宅街区・戸建専用街区の電源である PEFCの部分負荷損失には表-10の值を用いた.

$$
\begin{gathered}
\text { 負荷追従電源出力 }=\text { 発電計画量一ベース電源出力 } \\
\text { - 放電量 }
\end{gathered}
$$

\section{d）熱需給バランス評価モデル}

熱需給バランス算定モデルは，給湯用熱負荷とベース 電源・負荷追従電源から発生する排熱のバランスを評価 して，蓄熱量およびガスボイラ出力を設定するモデルで ある。まず，時刻別のベース電源出力と負荷追従電源出 力，表-10の部分負荷を考慮した排熱回収効率から，各 電源の排熱発生量を時刻別に算定した（式(17)）。なお, 街区内で配管を通じて排熱を融通する際に，5\%の熱損 失があるとしている。

次に，式(18)を用い，エネルギ一負荷算定モデルで求 めた時刻別の給湯熱負荷と排熱発生量の差を求めて，熱 の余剰量もしくは不足量を求めた．余剰熱が発生する場 合は，貯湯槽に蓄熱して，熱が不足する時間帯に放熱さ れるものとした．貯湯時の熱損失は16\%/日と設定した。

一方，給湯の熱負荷の方が多い場合は，ます貯湯分を利 用し，それでも不足する熱量に関しては，ガスボイラに より補った。

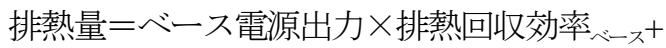
負荷追従電源出力 $\times$ 排熱回収効率負荷追従

$$
\text { ガスボイラ出力＝給湯負荷一排熱量 }
$$

\section{e) $\mathrm{CO}_{2}$ 排出量算定モデル}

以上で算出されたベース電源出力, 負荷追従電源出力, ガスボイラ出力量から都市ガス使用量を求め, 都市ガス の $\mathrm{CO}_{2}$ 排出原単位 ${ }^{36}$, 37) 乗じることでCO ${ }_{2}$ 排出量を推算す る. 式(19)を用いて， ベース電源・負荷追従電源用のガ ス使用量は，それぞれの出力量を発電効率で除すること で求めた。 ガスボイラ用での都市ガス消費量は，ガスボ イラの出力を熱変換効率 ${ }^{38)}: 90 \%$ で除して求めた。 これ ら各電源・ボイラのガス使用量を合計し，年間のガス消 費量をメッシュ単位で求め, 都市ガスの $\mathrm{CO}_{2}$ 排出原単位 を乗じることでCO 2 排出量を算出した.

都市ガス消費量=ベース電源用ガス使用量

十負荷追従電源用ガス使用量十ボイラ用ガス使用量

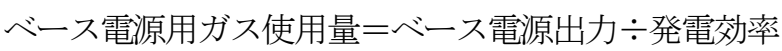

表-12 $\mathrm{CO}_{2}$ 排出原単位

\begin{tabular}{c|r|c|c|c}
\hline 電気 & 都市ガス & LPG & 灯油 & A 重油 \\
\hline 0.3984 & 0.0509 & 0.0598 & 0.0674 & 0.0712 \\
\hline$\left[\mathrm{kg}-\mathrm{CO}_{2} / \mathrm{kWh}\right]$ & \multicolumn{5}{|c}{$\left[\mathrm{kg}-\mathrm{CO}_{2} / \mathrm{MJ}\right]$} \\
\hline
\end{tabular}

負荷追従電源用ガス使用量 $=$ 負荷追従電源出力

$\div$ 発電効率

ボイラ用ガス使用量 $=$ ガスボイラ出力 $\div$ 熱変換効率

$\mathrm{CO}_{2}$ 排出量=都市ガス消費量 $\times \mathrm{CO}_{2}$ 排出原単位

\section{（7）選択的導入ケースの計算手法}

選択的導入ケースは，個別HPシステム・マイクログ リッドシステムのどちらかが選択される場合を評価する. 5年ごとの各年代ごとに建設される着工床面積に応じて， メッシュごとに両システムの年間 $\mathrm{CO}_{2}$ 排出量を推計し, $\mathrm{CO}_{2}$ 排出削減効果が大きいシステムが選択されるとした.

\section{（8）未更新建物の $\mathrm{CO}_{2}$ 排出量の算定手法}

更新されない床面積（未更新建物）に導入されている 従来のエネルギーシステムからのエネルギー消費量を計 算する. 現状の然料種別エネルギー消費原単位に，年代 ごとの未更新建物床面積を乗じることでエネルギー消費 量を燃料種別に算出し，それぞれの燃料の $\mathrm{CO}_{2}$ 排出原単 位帛をを乗じることで未更新建物の $\mathrm{CO}_{2}$ 排出量を算定した. 本研究で用いる $\mathrm{CO}_{2}$ 排出原単位を表-12にまとめる.

\section{4. 大阪市へのモデル適用と評価}

\section{(1) 集約型都市設計モデルによる推計結果 \\ a) 拠点選定結果}

現状用途地域推定サブモデルと拠点選定サブモデルを 大阪市に適用し，各メッシュの用途地域を決定させた. 用途地域別のメッシュ数とその割合を表-13，表-14に，

表-13 現状用途地域推定サブモデルによる選定結果

\begin{tabular}{c|l|r|r}
\hline 番号 & 用途地域 & メッシュ数 & 割合 $(\%)$ \\
\hline 10 & 第1種低層住居専用地域 & 642 & 18.2 \\
\hline 20 & 第2種低層住居専用地域 & 86 & 2.4 \\
\hline 30 & 第1種中高層住居専用地域 & 316 & 8.9 \\
\hline 40 & 第2種中高層住居専用地域 & 122 & 3.5 \\
\hline 50 & 第1種住居地域 & 666 & 18.8 \\
\hline 60 & 第2種住居地域 & 156 & 4.4 \\
\hline 70 & 準住居地域 & 61 & 1.7 \\
\hline 80 & 近隣商業地域 & 262 & 761 \\
\hline 90 & 商業地域 & 310 & 13.0 \\
\hline 100 & 準工業地域 & 113 & 8.8 \\
\hline 110 & 工業地域 & 340 & 3.2 \\
\hline 120 & 工業専用地域 & \multicolumn{2}{|c}{} \\
\hline
\end{tabular}

表-14 拠点選定サブモデルによる選定結果

\begin{tabular}{c|l|r|r}
\hline 番号 & 用途地域 & メッシュ数 & 割合 $(\%)$ \\
\hline \hline 1 & 高度集積地域 & 172 & 4.8 \\
\hline 2 & 準集積地域 & 256 & 7.2 \\
\hline 3 & 商住混在地域 & 412 & 11.5 \\
\hline 4 & 集合住宅地域 & 495 & 13.8 \\
\hline 5 & 戸建専用地域 & 1,155 & 32.3 \\
\hline 6 & 市街化調整地域 & 449 & 12.5 \\
\hline 7 & 多用途混在地域 & 592 & 16.5 \\
\hline 8 & 空白地域 & 48 & 1.3 \\
\hline
\end{tabular}


選定結果をGIS上で図示したものを図-10, 図-11に示す. b) 床面積需要推計結果

将来床面積需要推計モデルより, 将来の床面積需要を 建物用途別・メッシュ別に5年間隔で算出した. 結果を 図-12に示す，人口の減少とともに，必要な床面積は減 少していく推計が得られており，2020年時点で2005年比 4.6\%の減少，2050年には同22.0\%の減少と推計された。

\section{c) 更新床面積の推計結果}

大阪市における将来の年代別更新床面積推計結果を図 -13に示す．1階床面積でみると2010～2030年までは一定 の床面積が更新されると推計されており，開発可能な土 地もこの期間に多く存在することが想定される. 他方, 延床面積は2030年まで緩やかに上昇しその後減少に転じ るが，1階床面積ほど2035年以降の減少幅は少ない結果 となった．以上より，更新される建物の1階床面積が多 く, 開発できる土地面積が多い2030年までの都市開発の 方向性が，都市構造転換の大きな鍵となることが分かる.

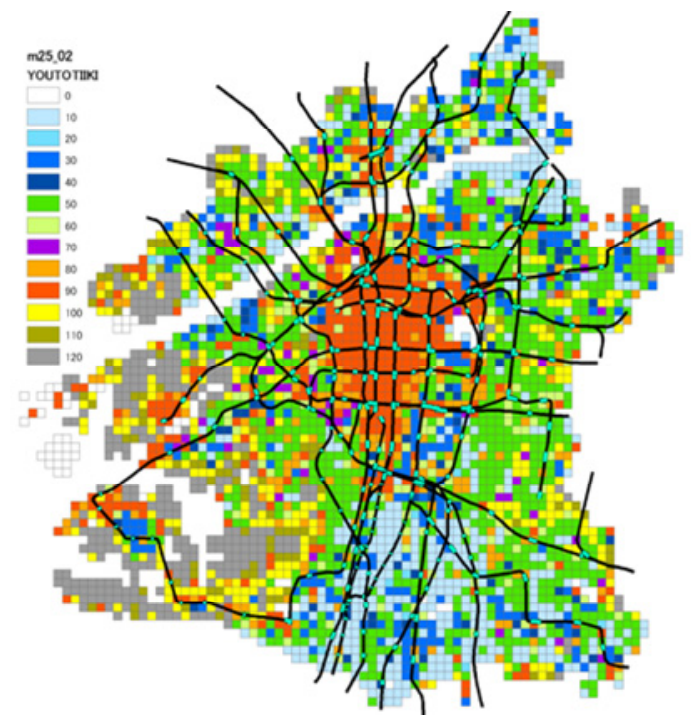

図-10 現状用途地域推定結果（凡例は表-13に同じ）

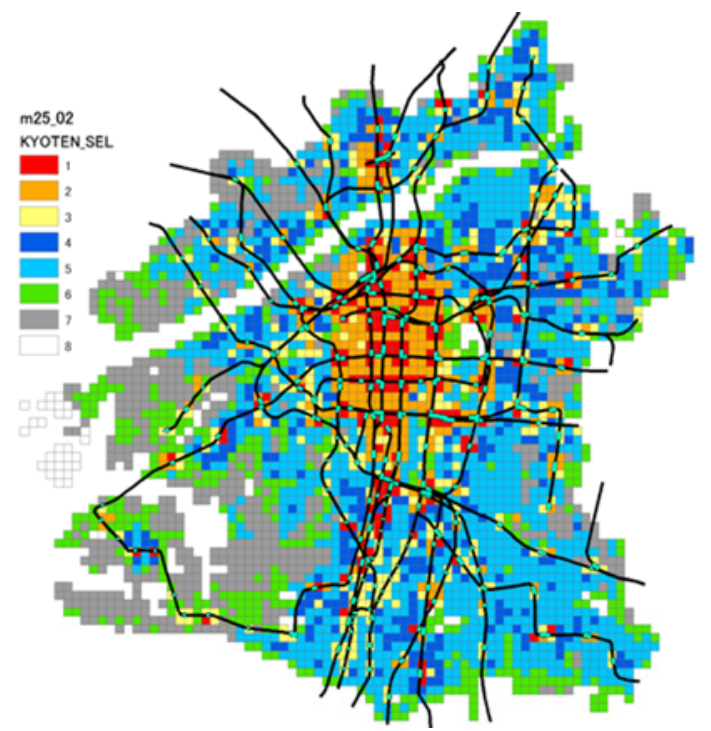

図-11 新規用途地域の設定結果（凡例は表-14に同じ）

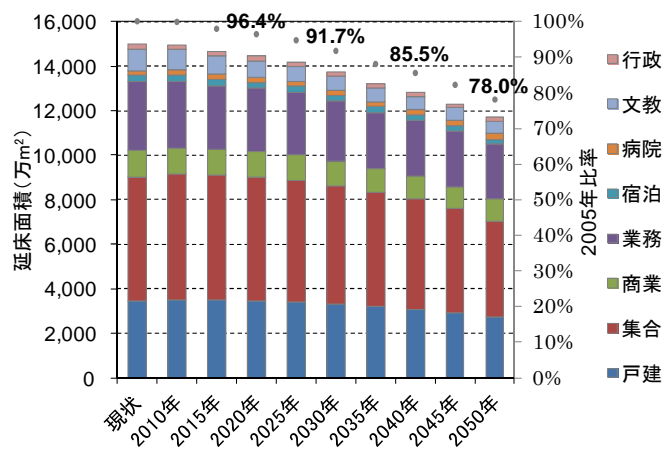

図-12 大阪市将来床面積需要推計結果

口戸建 口集合口商業口業務口宿泊口病院口文教口行政
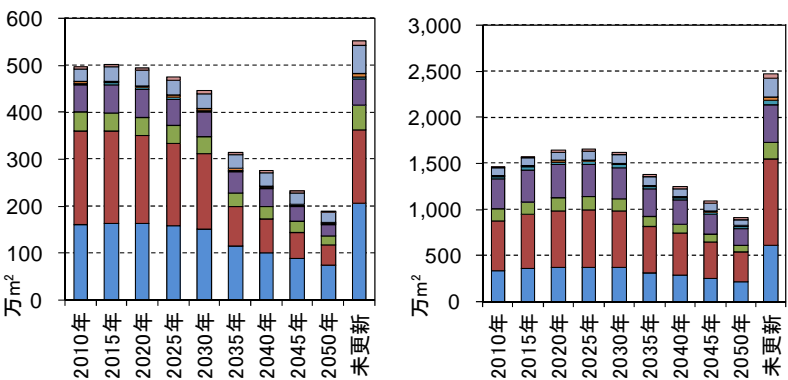

図-13 更新床面積 (左 : 1階床, 右 : 延床面積)

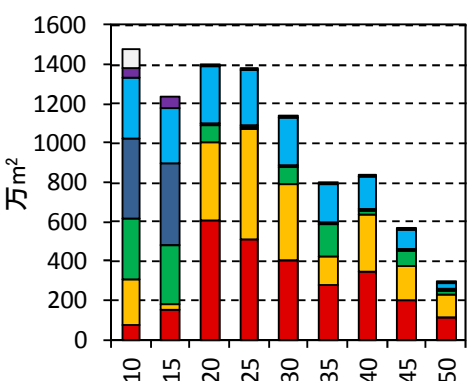

口市街化調整

口多用途混在

口戸建住宅専用

口集合住宅

口商住混在

口準集積

口高度集積

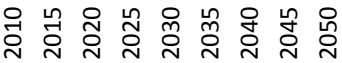

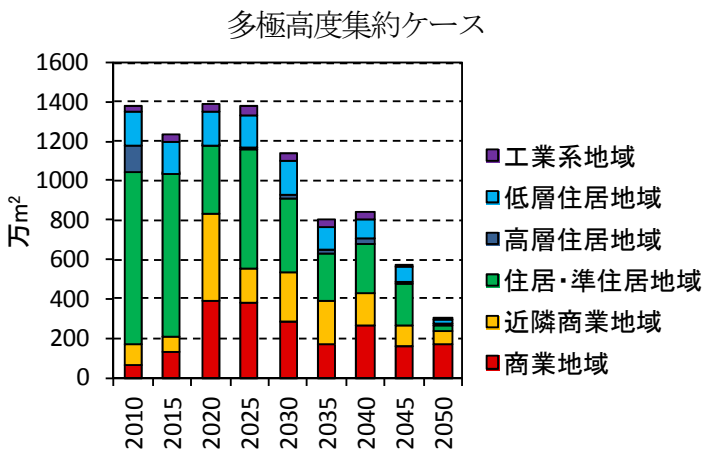

多極普通集約ケース

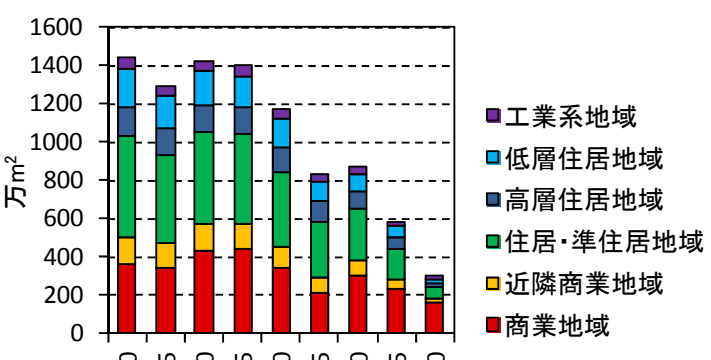

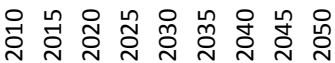

傾向延長ケース

図-14＼cjkstart新規建設床面積年代別推移 


\section{d) 新規建設床面積の推計結果}

集約型都市設計モデルによりケース別に算出される新 規建設床面積を5年ごと，都市構造ケース別に図-14に示 す．比較すると，建物床面積の集約を実施する2ケース

（多極高度集約，多極普通集約）において初年度期に, 拠点に建設される床面積（図中，赤・オレンジ地域）が 少なくなっている．これらのケースでは最低開発床面積 制限を設けており，初期にはほとんどのメッシュで条件 を満たす開発可能な空地が確保できないため，このよう な推移となっている．2020年には多くのメッシュにおい て開発可能な土地が利用できるようになり，集約拠点に おいて多くの開発が行われるようになる.したがって, 今後，大阪市において大規模な開発を都市全体で実行す るためには，10年程度，小規模な都市の開発を管理する 必要があることが示唆される.

\section{e) 将来床面積ストック推計結果}

集約型都市設計モデルより推定される2050年の床面積 ストックのグロス容積率を図-15に示す。現状の都市構 造が維持する傾向延長ケースでは，中密度な地域が広範 囲に広がっている．他方，多極高度集約ケースでは駅周 辺を中心に高容積が達成されている．また，多極普通集 約ケースは，中低密な地域が広がる一方で集約化する拠 点も適宜分散的に存在しており,メリハリのある土地利 用となっている.

\section{(2) 省エネルギーシステム導入によるCO $\mathrm{Cl}_{2}$ 減効果}

\section{a) 都市構造ケース別 $\mathrm{CO}_{2}$ 排出量の比較}

省エネルギーシステム導入評価モデルより推計される 2050年のCO 排出量を図-16に示す．現状（2005年）と比 較すると，人口減少により無対策でも $22 \% の \mathrm{CO}_{2}$ 排出が 減少する. OA機器・照明，断熱性能を向上させること で36.5\%（無対策との比で約15\%）のCO 2 削減が可能とな る.さらに，本研究で対象とした次世代の省エネルギー システムを構築することで, 各都市構造ケースともに 54.8〜 57.6\%の削減が達成されることが分かった。 どのケ 一スにおいても更新建物に省エネルギーシステムを導入 していくことで順次 $\mathrm{CO}_{2}$ 排出削減が可能であり，2030年 時点でも，およそ32〜34\%のCO 2 削減が達成される推計 となった．ただし，このような建物の建て替わりに合わ せた省エネルギーシステムの導入は長期的かつ継続的な 施策は必要とされ，現在から順次計画的に省エネルギー システムを導入していくことが求められる.したがって, 更新建物に適切に省エネルギーシステムが導入されない 場合や対策の実施が遅れた場合には，2050年にCO 量を半減させるという大幅な削減は達成できない可能性 があることには留意しなければならない.

次に, 都市構造間の選択導入ケースで比較すると，傾 向延長ケースの $\mathrm{CO}_{2}$ 排出削減率が最も高く, より高密に
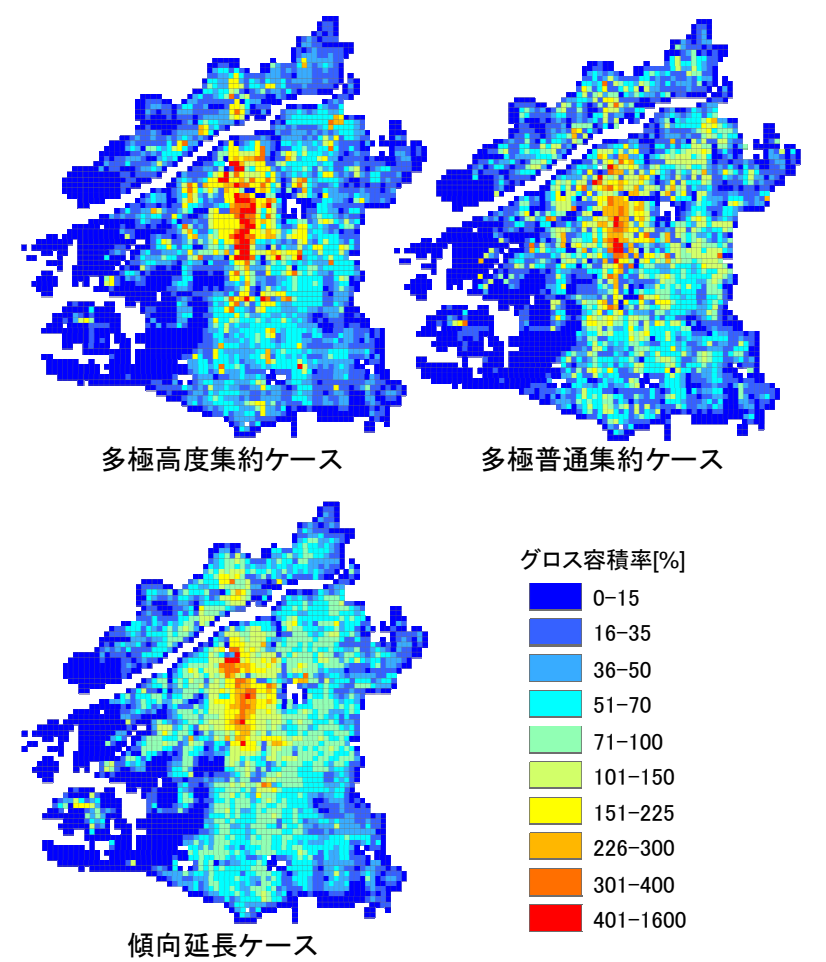

図-15 大阪市2050年床面積ストックのグロス容積率

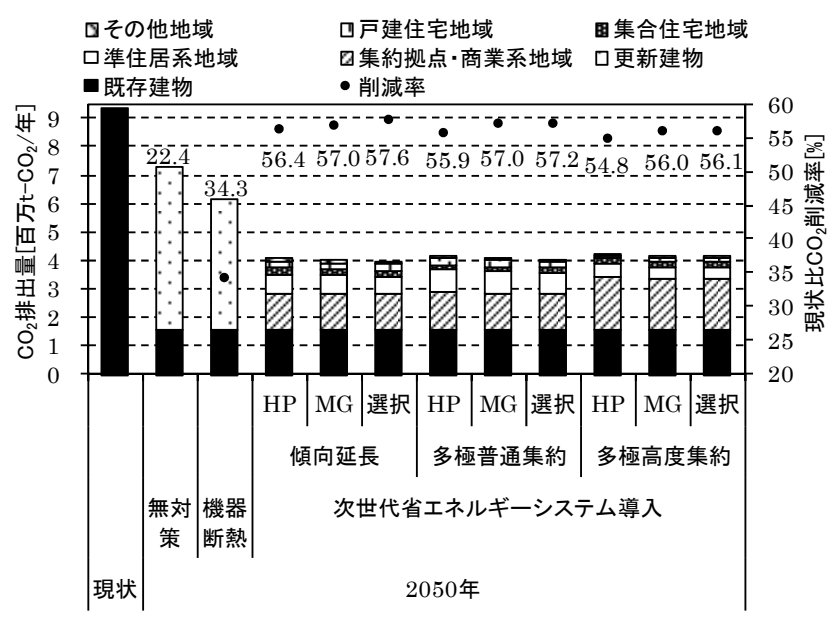

図-16 2050年 $\mathrm{CO}_{2}$ 排出量の比較

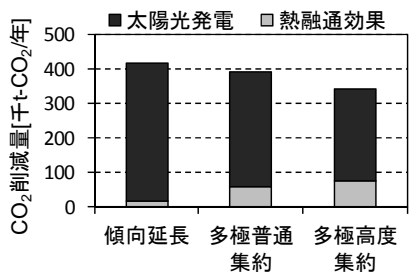

晴れ

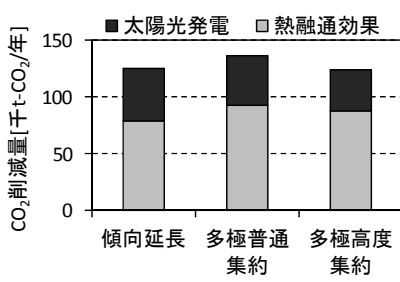

雨

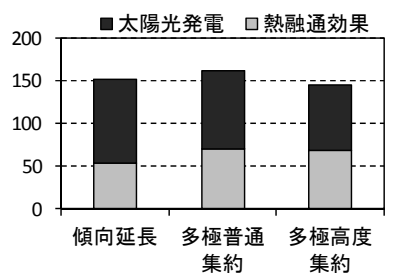

量り

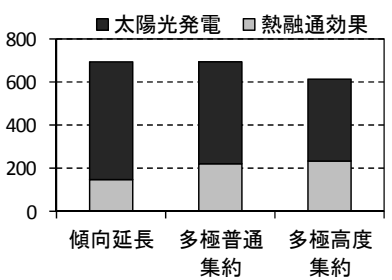

合計
図-17 太陽光発電及び熱融通による $\mathrm{CO}_{2}$ 排出削減量（選択） 
集約させる多極普通集約ケース，多極高度集約ケースの 順に， $\mathrm{CO}_{2}$ 削減量が若干ながら低下している。これは， 集約化による熱の融通利用効果よりも太陽光発電の導入 効果が上回ること，大阪市は現状で商住混在している地 域が多く傾向延長ケースでも負荷平準効果が得られ易か ったことに由るところが大きいと考えられる. そこで, 太陽光発電, 熱融通による $\mathrm{CO}_{2}$ 削減量を天候別に推計し た結果を図-17に示す。なお，熱融通による $\mathrm{CO}_{2}$ 削減量 （式(20)）は，燃料電池CGSの負荷追従電源・ベース電 源からの排熱のうち, 融通利用できた熱量から, 追加ボ イラによる熱量を差し引いたものを正味の削減量と考え， これに都市ガスの $\mathrm{CO}_{2}$ 排出原単位を乗じて算出した.

熱融通によるCO 2 削減量 $=$

(融通利用熱量一ボイラ熱量) $\times \mathrm{CO}_{2}$ 排出原単位

これによると，晴天時の太陽光発電による削減量が多 く，熱の融通利用分を打ち消していることが分かる．合 計すると，太陽光発電の導入量が少ない多極高度集約ケ 一スはCO削減量が低下している，また，熱の融通効果 の夕に着目寸ると, 傾向延長から多極普通集約一は飛躍 的に削減量が伸びるものの，多極高度集約では削減効果 の上乗せが少ないことが分かる．建物床面積を単に高密 化させるのではなく, 負荷の平準化を図る形での用途混 在を計画的に行うことが必要と言える.

表-15 代表メッシュの設定

\begin{tabular}{|c|c|c|c|c|c|}
\hline \multirow[t]{2}{*}{ 街区類型 } & \multirow[t]{2}{*}{ メッシュコード } & \multicolumn{4}{|c|}{$\begin{array}{c}\text { 上段: 建物用途別床面積 }\left(\mathrm{m}^{2}\right) \\
\text { 下段: 割合 }(\%)\end{array}$} \\
\hline & & 戸建 & 集合 & 商業 & 業務 \\
\hline \multirow{2}{*}{ 高度集積地域 } & \multirow{2}{*}{ N005E0102 } & 0 & 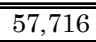 & 17,315 & 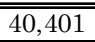 \\
\hline & & $0 \%$ & $50 \%$ & $15 \%$ & $35 \%$ \\
\hline \multirow{2}{*}{ 準集積地域 } & \multirow{2}{*}{ N005W0301 } & 0 & 32,908 & 5,625 & 16,314 \\
\hline & & $0 \%$ & $60 \%$ & $10 \%$ & $30 \%$ \\
\hline \multirow{2}{*}{ 集合住宅地域 } & \multirow{2}{*}{ N005E0552 } & 0 & 13,879 & 0 & 0 \\
\hline & & $0 \%$ & $100 \%$ & $0 \%$ & $0 \%$ \\
\hline \multirow{2}{*}{ 戸建住宅地域 } & \multirow{2}{*}{ N005E0354 } & 5,012 & 0 & 0 & 0 \\
\hline & & $100 \%$ & $0 \%$ & $0 \%$ & $0 \%$ \\
\hline
\end{tabular}
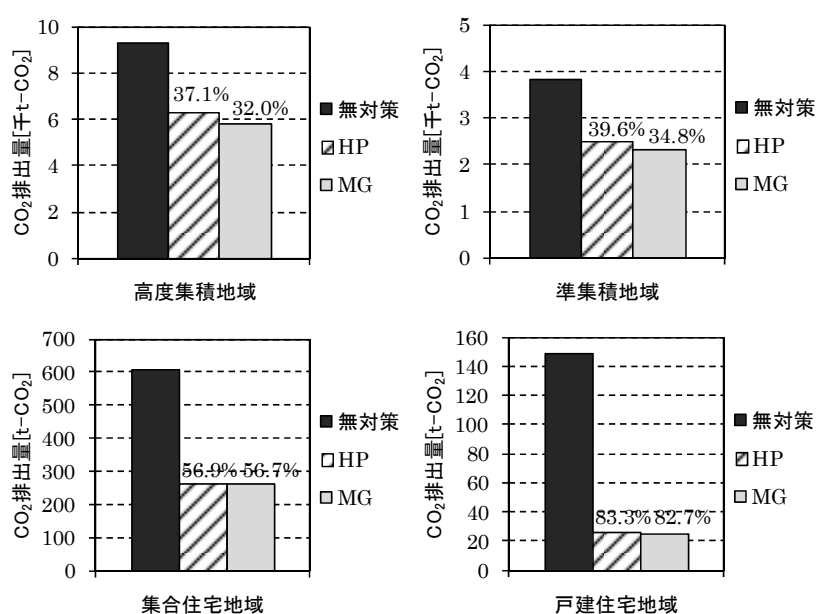

図-18 街区類型別 $\mathrm{CO}_{2}$ 排出量（表-15の代表メッシュに対応）

\section{b) 街区類型別}

本節では，街区類型ごとに省エネルギーシステム導入 による $\mathrm{CO}_{2}$ 排出削減効果を比較・検討するため，表-15に 示寸多極高度集約ケースの代表メッシュ（2020年の着工 の高度集積街区，準集積街区，集合住宅街区，戸建住宅 専用街区）を分析する．なお，多極普通集約ケースで用 いる現状の用途地域についても，拠点における用途混在 比率は同じであり, エネルギーシステム別の $\mathrm{CO}_{2}$ 排出量 の傾向は同様である.

図-18に街区類型別の2050年 $\mathrm{CO}_{2}$ 排出量推計結果を示寸. 図中の数值は無対策からの削減率である. これより, 両 システムともに戸建住宅地域で83\%程度の大きな削減効 果があることが分かる．これは，戸建住宅は延床面積に 対する屋根面積の比率が大きく, 太陽光発電による $\mathrm{CO}_{2}$ 削減量が大きいためである. 省エネルギーシステム別に みると, 集積拠点の 2 地域でマイクログリッドシステム が個別電化HPケースに比べて5\%程度, 削減効果が大き くなった. これは，負荷の平準化によって熱を有効利用 できているためであり，住宅用途しか存在しない集合住 宅や戸建住宅地域では，両システムがほぼ同等となった。

\section{c）都市民生エネルギ一供給構造の比較}

大阪市民生部門全体における2050年の種別エネルギー 供給量を都市構造ケース別・エネルギーシステムケース 別に比較する（図-19）．個別電化HPケースでは，更新 建物において全電化方式が順次採用され，2050年時点で, どの都市構造でも系統電力への依存が顕著となり, 都市 ガスのエネルギー供給量の比率は約13\%となる。これに 対し，選択導入ケースでは商住が混在した集積拠点を中 心にマイクログリッドシステムが選択され，都市ガスの 比率が高くなる. 特に, 高密に集積する多極高度集約ケ 一スで都市ガス比率が最も高く $78.2 \%$ となり, 次いで多 極普通集約ケースの69.6\%, 傾向延長ケースの67.8\%とな っている.ここで, 優位となるエネルギーシステムの選 択は, 機器効率や $\mathrm{CO}_{2}$ 排出係数等の設定によって左右さ れる点に留意しなければならず，建物や街区の条件を踏

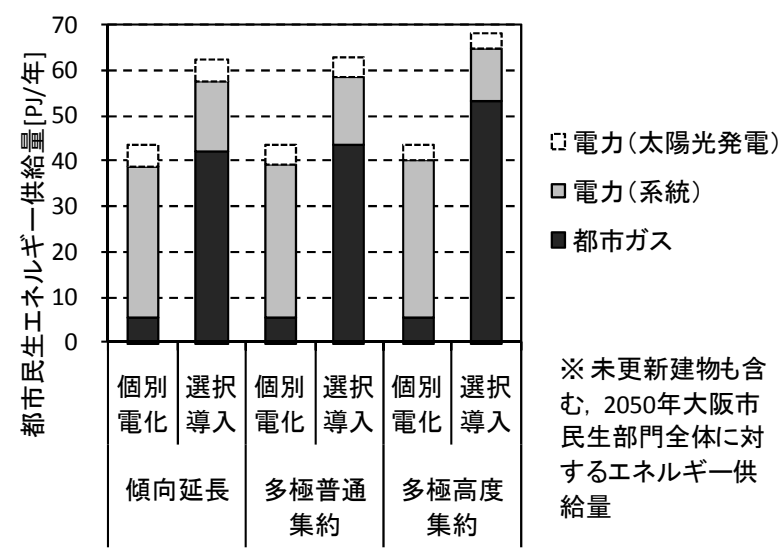

図-19 2050年における都市民生エネルギー供給量の比較 
まえたより精緻な評価が求められるが，都市全体で評価 した場合には，都市を高密化することによりマイクログ リッド等の都市ガスを主体とするエネルギーシステムの 優位性が高まる傾向が明確となった。

したがって， $\mathrm{CO}_{2}$ 排出削減の観点からは，傾向延長の ような低密な都市構造においても，全電化を推し進めて いくことで一定の効果が得られるが，エネルギー源とし て系統電力に大きく依存するエネルギ一供給構造となる. これに対し，図-17より建物床面積を集約することで熱 融通による $\mathrm{CO}_{2}$ 削減効果が得られ易くなっており，都市 ガスをより効率的に利用できる都市構造となることが分 かる．災害等に備えて都市民生部門の需要端機器への工 ネルギー供給源を系統電力と都市ガスに分散化させた上 で，図-16のようにほぼ同レベルのCO 2 排出削減効果が得 られていることが，集約型の都市構造の長所である.

\section{5. おわりに}

本研究では，建物の更新から都市計画制度の違いを考 慮し，更新場所・時期，建て替え場所を設定し床面積を 配分するという建物更新の流れに沿って将来の都市構造 が表現できるモデルと，省エネルギーシステムが導入さ れた場合の $\mathrm{CO}_{2}$ 排出量を定量化し，低炭素施策の評価が 可能なモデルを構築した．本研究で開発したモデルを大 阪市に適用することで，用途別建物床面積の集約度合い や集積拠点の異なる複数の都市構造を，現実的な都市更 新に則した形で表現できることを示した.

3つの集積度合いの異なる都市構造下での省エネルギ ーシステム導入施策の評価結果は以下の通りである.

- 個別機器効率の向上，建物性能の向上だけでなく, 高効率なHPシステムの導入や街区レベルで電熱融 通を行うマイクログリッドシステムなどの高効率な システムを更新される建物に順次導入していくこと で，54.8〜57.6\%の大幅な $\mathrm{CO}_{2}$ 排出削減が可能である という推計を得た。その際，適切な商住混在が図れ た街区にはマイクログリッドシステムが有利であり， 燃料電池の排熱を有効利用寸ることが望まれる.

- 都市構造ケース別にCO 排出削減量を比較すると, 都市構造の高密化を図らない傾向延長ケースの削減 量が最も大きくなった．これは，低密な都市構造の 方が太陽光発電を導入できる屋根面積が多く, これ による $\mathrm{CO}_{2}$ 削減効果が大きく作用するためである. 将来の人口減少局面において, 過度な都市の高密化 は太陽光発電の利用可能量が減少するため有効では なく, 太陽光発電の導入可能性と都市構造の関係は 検討されるべき事項である.

・ 都市を高密化するに従い，選択導入ケースにおいて
マイクログリッドシステムを選択する街区の比率が 増え，都市民生エネルギーの供給構成に占める都市 ガスの割合は多極高度集約ケースで78.2\%まで増加 した．大災害や燃料価格の変動に備えて，都市民生 部門の需要端機器へのエネルギー供給源を分散化し ておくというリスク・ガバナンスの視点では，系統 電力と都市ガスのベストミックスという考えが重要 となり, 都市ガスを効率的に利用できる集約型の都 市構造は優位性が高まる. 寸なわち, 複数のエネル ギー源を利用し，かつ $\mathrm{CO}_{2}$ 排出の削減を達成するた めには，都市を集約化し，商住混在の集積街区を中 心に適切にマイクログリッドシステムを導入してい くことが必要である.

本研究では, 計画的な都市の高密化・建物床面積の集 積による民生部門のCO 2 排出削減効果は, 都市全体で評 価した際には示されなかった，ただし，商住を混在させ ながら建物を高密に集積させた街区では，給湯熱だけで なく冷暖房需要を含めた熱融通システムが利用できるた め，高密な都市構造の削減ポテンシャルが過小評価され ている可能性がある. 一方で, 将来的に系統電源の $\mathrm{CO}_{2}$ 排出原単位が低下寸ることや，太陽光発電の効率がより 一層高くなることが，低密な都市構造を有利とする要因 として挙げられる．また，技術的な要因のみでなく，将 来的な産業構造や都心居住人口の変化に応じて，用途別 の建物床面積の混在度合いが変化し，熱融通が有利とな る用途混在型の高密度街区を形成できる面積も変わりう る. 本研究で得られた分析結果は, 将来の社会経済状況 や技術性能に関する設定值や，選択した導入技術に基づ き得られたものであり，各パラメータの設定によって優 位となる都市構造が異なる可能性がある点に留意が必要 となる，とりわけ，技術開発動向が建物床面積の集積に よる $\mathrm{CO}_{2}$ 排出削減効果に大きく影響するため，予測の精 度を高めるとともに，技術性能に関する多様な将来予測 值の下での分析事例を増やすことが望まれる．合わせて， 地域性の差異に関する分析も検討課題である．他の都市 において，冷暖房需要や給湯需要に影響寸る気象条件が 異なることや，大阪市では既に高い状態にあった街区内 での商住混在度合いなどの都市構造の違いに留意し，各 都市で建物集積による民生用エネルギー消費の改善効果 を評価する必要がある.

さらに，今回は既存の交通インフラである駅を中心に 集積することを前提としたが，公共サービスの効率化や 防災上の観点から，学校や病院等も集積拠点となり得る。 したがって，公共性の高い施設の配置も考慮し，将来の 都市構造について総合的に検討できる拠点選定モデルに 改良することも，今後の課題として挙げられる. 
謝辞 : 本研究は，科学研究費補助金・挑戦的萌芽研究 22651015 「技術リスクガバナンスのプロトタイプモデル 構築」の支援を得て実施されました。また，本研究のモ デル開発にあたり，大阪市計画調整局より建物床面積デ 一タを提供して頂きました。記して謝意を表します。

\section{参考文献}

1) 下田吉之，山口容平，浅井崇志，水野稔：地区を基 本単位とした都市エネルギー需要のモデル化と将来 シナリオに関する研究, 日本都市計画学会論文集, No. 41-3, pp.833-838, 2006.

2) Yamaguchi, Y., Shimoda, Y., and Mizuno, M.: Proposal of a modeling approach considering urban form for evaluation of city level energy management, Energy and Buildings, Vol.39, pp. 580-592, 2007.

3) 海道晴信：コンパクトシティの計画とデザイン，学 芸出版社， 2007.

4) 伊藤滋 : 低炭素化と都市計画, <http://www1k.mesh.ne. jp/toshikei/241.htm>，2011.2.15参照.

5) 石田武志, 森俊介 : 都市街区内におけるマイクログ リッド等の分散エネルギーネットワーク評価モデル の構築，エネルギーシステム・経済・環境コンファ レンス講演論文集，第 22 巻，pp.187-190， 2007.

6) 田頭直人：都市の空間構造が $\mathrm{CO}_{2}$ 排出削減効果に与 える影響一地域冷暖房及び太陽光発電システムの導 入を考慮して一, 電力中央研究所 研究報告書, Y020 15, 2003

7) 横井隆志, 山本祐吾, 東海明宏, 盛岡通: 低炭素都 市の形成に向けた街区更新およびエネルギー計画の 統合を支援するシステム開発，土木学会論文集 $G$, Vol.66, No.1, pp.17-34, 2010.

8) 大阪市計画調整局 : 平成 18 年度 建物床面積調查.

9) 大阪市計画調整局 : 平成 17 年度 土地利用現況調查.

10）及川智，占部武生：建設廃棄物の発生抑制に関寸る 研究（その 1) 一東京 23 区の建築ストック量と建築 物の寿命, 解体建築物床面積の将来予測一, 東京都 環境科学研究所年報 2002, pp.182-190, 2002.

11) 大阪市計画調整局：平成 17 年国勢調査 町丁目別資 料, <http://www.city.osaka.lg.jp/keikakuchosei/page/000 0018742.html $>$, 2011.2.15 参照.

12) 国立社会保障・人口問題研究所：日本の市区町村別 将来推計人口（平成 20 年 12 月推計），政令市の区 別男女 5 歳階級別データ，08.大阪市，2008.

13) 大阪市：平成 19 年度 大阪市民経済計算， 2010.

14）日本経済研究センター：長期経済予測（2006～2050 年），2007，<http://www.jcer.or.jp/research/long/detail3 532.html>，2011.2.15参照.

15) 大阪府 : 大阪府都市計画区域マスタープラン，2000.

16）叶明超, 加藤丈佳, 鈴置保雄 : 都市再生に伴うエネ ルギー需給の高効率化のための一考察-地区ごとの需 要集中と小規模熱供給の導入効果-, 第 21 回エネルギ ーシステム・経済・環境コンファレンス講演論文集， pp.113-116，2005.

17) 谷口綾子, 下田吉之, 山口幸男 : 都市家庭用エンド ユースモデルの全国への応用(6)，第 24 回エネルギー システム・経済・環境コンファレンス講演論文集, $p$ p.561-564, 2008.

18）菅正史，大西隆：発電排熱を活用する地域エネルギ
ーシステムの効率性評価の課題に関する一考察，日 本都市計画学会都市計画論文集, No.43-3, pp.133-13 8, 2008.

19) 岡村廸夫 : 電気二重層キャパシタと蓄電システム, 日刊工業新聞社，2001.

20) 気候ネットワーク：2020 年の 30\%削減社会ビジョン を描く〜家庭・業務部門の削減シナリオと政策提案 $\sim, 2006$.

21) 財団法人 金属系材料研究開発センター：高効率電光 変換化合物半導体開発（21 世紀のあかり計画）成果 報告書, 2004.

22) 河本薰, 辻浦享子, 下田吉之, 水野稔 : OA 機器の使 用実態調査と電源管理による省電力効果の評価，第 1 8 回エネルギーシステム・経済・環境コンファレンス 講演論文集, pp. 617-622, 2002.

23）社団法人 日本ビルエネルギー総合管理技術協会 : 才 フィスビルにおける OA 機器のエネルギー消費実態 調査報告書, pp.16-70, 1999.

24) 経済産業省：Cool Earth -エネルギー革新技術計画（概要）， 2008.

25）合田忠弘ほか共著：マイクログリッド，(社)日本電気 協会新聞部, 2004.

26) Fukushima, Y., Shimoda, M., Kraines, S., Hirao, M., and Koyama, M.: Scenarios of solid oxide fuel cell introduction into Japanese society, Journal of Power Sources, No. 131, pp. 327-339, 2004.

27) 富士経済: 平成 15 年度ロードカーブ改善対策技術等 調査（分散型エネルギー供給システム将来普及展望 予測調查）報告書, 2004 .

28) 国土交通省：住宅・建築分野における地球温暖化対 策について，2007.

29) 深沢大樹, 村橋善満, 外岡豊, 三浦秀一：日本の住 宅部門における温室効果ガス排出削減対策の検討 そ の 2 断熱性能向上と高効率家電機器の普及による地 域別対策効果の算定, 第 20 回エネルギーシステム・ 経済・環境コンファレンス講演論文集, pp.293-296, 2004.

30）環境省中央環境審議会地球環境部会：2008～2012 年 度の温室効果ガス排出量の推計（現状対策ケース, 対策強化ケース），2004.

31) 日本エネルギー学会 : 天然ガスコージェネレーショ ン計画・設計マニュアル 2005, 日本工業出版, 2005.

32) 高橋伸英 : S-3 脱温暖化社会に向けた中長期的政策才 プションの多面的かつ総合的な評価・予測・立案手 法の確立に関する総合研究プロジェクト，3.都市に対 する中長期的な二酸化炭素排出削減策導入効果の評 価，(4)都市への燃料電池と太陽電池導入によるエネ ルギー削減効果，<http://2050.nies.go.jp/material/>

33）財団法人日本気象協会ホームページ，<http://www.jwa. or.jp/content/view/full/1954/>，2011.2.15 参照.

34）財団法人日本気象協会ホームページ，過去の気象デ 一夕検索, <http://www.data.jma.go.jp/obd/stats/etrn/inde x.php>，2011.2.15日参照.

35) 兵庫県環境審議会大気環境部会 : 電気事業者別電力 排出係数の推移, 2010 年 2 月, <http://www.pref.hyog o.jp/JPN/apr/shingi/atmosphere/H220421/sankou06.pdf>, 2011.2.15 参照

36) 東京ガス : 都市ガスの $\mathrm{CO}_{2}$ 排出係数, <http://www.tok yo-gas.co.jp/env/gas/category08.html>, 2011.2.15参照. 
37) 大阪ガス : 都市ガスの使用による $\mathrm{CO}_{2}$ 排出量, <http:/ /www.osakagas.co.jp/kankyo/gas/03.html>, 2011.2.15 参 照.

38) 空気調和・衛生工学会 : 空気調和・衛生工学便覧 2 . 機器・材料編, 2010.
39) 環境情報科学センター： $\mathrm{CO}_{2}$ 排出原単位表(2007 年版), $<$ http://www.lifecycle.jp/manual/CO2_unit_2007.pdf>, 2 011.2.15 参照.

\title{
DEVELOPING AN INTEGRATED MANAGEMENT SYSTEM FOR URBAN AND ENERGY PLANNING TOWARDS A LOW-CARBON CITY
}

\author{
Hideto MAEDA, Toyohiko NAKAKUBO and Akihiro TOKAI
}

In this study, we developed an integrated management model that supports local government to make a promising energy saving measure on a block-scale combined with urban planning. We applied the model to Osaka city and estimated $\mathrm{CO}_{2}$ emissions from the residential and commercial buildings to 2050. The urban renewal cases selected in this study included advanced multipole accumulation case, normal multipole accumulation case, and actual trend continuation case. The energy saving options introduced in each case included all-electric HP system, micro grid system, and we also set the option where the greater $\mathrm{CO}_{2}$ reduction one is selected in each block. The results showed that $\mathrm{CO}_{2}$ emission in 2050 would be reduced by $54.8-57.6 \%$ relative to the actual condition by introducing the new energy system in all cases. In addition, the amount of $\mathrm{CO}_{2}$ reduction in actual trend continuation case was highest. The major factor was that the effect of $\mathrm{CO}_{2}$ emission reductions by installing the solar power generation panel was higher than the effect by utilizing heated water mutually on the high-density blocks in terms of total urban buildings' energy consumption. 